\title{
Spatial and temporal variability in nutrients and carbon uptake during 2004 and 2005 in the eastern equatorial Pacific Ocean
}

\author{
A. P. Palacz ${ }^{1, *}$ and F. Chai ${ }^{1}$ \\ ${ }^{1}$ School of Marine Sciences, University of Maine, Aubert Hall, 04469 Orono, ME, USA \\ *now at: National Institute of Aquatic Resources, Denmark Technical University, Jægersborg Allé 1, \\ 2920 Charlottenlund, Denmark
}

Correspondence to: A. P. Palacz (arpa@aqua.dtu.dk)

Received: 5 January 2012 - Published in Biogeosciences Discuss.: 18 January 2012

Revised: 3 October 2012 - Accepted: 4 October 2012 - Published: 8 November 2012

\begin{abstract}
The eastern equatorial Pacific plays a great role in the global carbon budget due to its enhanced biological productivity linked to the equatorial upwelling. However, as confirmed by the Equatorial Biocomplexity cruises in 2004 and 2005, nutrient upwelling supply varies strongly, partly due to the tropical instability waves (TIWs). The aim of this study was to examine patterns of spatial and temporal variability in the biological uptake of $\mathrm{NO}_{3}, \mathrm{Si}(\mathrm{OH})_{4}$ and carbon in this region, and to evaluate the role of biological and physical interactions controlling this variability over seasonal and intraseasonal time scales. Here, high resolution Pacific ROMS-CoSiNE (Regional Ocean Modeling System-Carbon, Silicon, Nitrogen Ecosystem) model results were evaluated with in situ and remote sensing data. The results of model-data comparison revealed a good agreement in domain-average hydrographic and biological rate estimates, and patterns of spatio-temporal variability in primary productivity. We confirmed that TIWs have the potential to enhance phytoplankton biomass through an increased supply of nutrients and elevated local and instantaneous phytoplankton nutrient uptake as opposed to only advecting biomass. Furthermore, we concluded that initial biological conditions (e.g., zooplankton biomass) may play an important additional constraint on biological responses, in particular of large phytoplankton such as diatoms, to TIW-induced perturbations in the physical and biogeochemical fields and fluxes. In order to fully resolve the complexity of biological and physical interactions in the eastern equatorial Pacific, we recommended improving CoSiNE and other models by introducing more phytoplankton groups, variable Redfield and carbon to chlorophyll ratios, as well as resolving the $\mathrm{Fe}-\mathrm{Si}$ co-limitation of phytoplankton growth.
\end{abstract}

\section{Introduction}

The eastern equatorial Pacific (EEP) plays a great role in the global carbon (C) cycle due to its enhanced biological productivity linked to the equatorial upwelling. Encompassing the equatorial upwelling zone (EUZ; $3^{\circ} \mathrm{S}-3^{\circ} \mathrm{N}, 140^{\circ} \mathrm{W}-$ $90^{\circ} \mathrm{W}$ ), the EEP provides the largest natural oceanic source of $\mathrm{CO}_{2}$ into the atmosphere at about 0.7 to $1.0 \mathrm{Pg} \mathrm{Cyr}^{-1}$ (Takahashi et al., 2003). Primary productivity (PP) in the EEP is significantly greater than in any other open ocean province, with an average value of $642 \mathrm{mg} \mathrm{C} \mathrm{m}^{2} \mathrm{~d}^{-1}$ (Pennington et al., 2006). Due to the large areal extent of the EEP, its new production is estimated to account for $18 \%$ of global new production (Chavez and Toggweiler, 1995). Despite the very high biological productivity, the EEP is a so-called "High Nitrate, Low Chlorophyll" (HNLC) region, with excess nitrate $\left(\mathrm{NO}_{3}\right)$ and unexpectedly low chlorophyll $a(\mathrm{Chl})$ concentrations in the surface waters (Minas et al., 1986; Dugdale and Wilkerson, 1998). The EEP is characterized by a strong zonal and meridional gradient in nutrient concentrations (iron $-\mathrm{Fe}$, nitrogen $-\mathrm{N}$, silicon $-\mathrm{Si}$ ) and in surface $\mathrm{Chl}$ concentrations (Pennington et al., 2006). The highly variable supply of nutrients via upwelling into the EEP surface waters constitutes an important factor in regulating local phytoplankton production (Wells et al., 1999; Christian et al., 2002; Gorgues et al., 2010). As a result, phytoplankton (especially diatom) production is said to be controlled by the availability of Fe (Behrenfeld et al., 1996; Aufdenkampe et al., 2002) and Si (Dugdale and Wilkerson, 1998; Dugdale et al., 2007), with both nutrients affecting different components of the phytoplankton, and on different time scales (Brzezinski et al., 2011). El Niño-Southern Oscillation (ENSO)

Published by Copernicus Publications on behalf of the European Geosciences Union. 
(Wang and Fiedler, 2006, and references therein), the Central Pacific El Niño (Turk et al., 2011), Pacific Decadal Oscillation (Mantua and Hare, 2002) and, potentially, climate change (Mestas-Nunez and Miller, 2006; Vecchi and Wittenberg, 2010) can all affect the long-term variability in biological production. On intraseasonal to interannual time scales, variability is associated with the occurrence of internal gravity waves (IGWs, e.g., Friedrichs and Hofmann, 2001; Salihoglu and Hofmann, 2007), Kelvin waves (e.g., Kessler and McPhaden, 1995; Chavez et al., 1998), Rossby waves (e.g., Lawrence and Angell, 2000) and tropical instability waves (TIWs, e.g., Foley et al., 1997; Gorgues et al., 2005).

TIWs are said to be generated by the shear between several equatorial currents flowing in opposite directions (Philander, 1978). Satellite images of Chl (Strutton et al., 2001), sea surface temperature (SST; Chelton et al., 2001) and recently also sea surface salinity (SSS; Lee et al., 2012) revealed that TIWs distort the equatorial upwelling tongue into a wave like pattern. Traveling from east to west, these waves attain speeds of $50 \mathrm{~km} \mathrm{~d}^{-1}$, wavelengths of $1000 \mathrm{~km}$ and periods of 17 to 33 days (Lyman et al., 2007). TIWs can also be characterized as trains of off-equator vortexes (tropical instability vortices, TIVs) (Flament et al., 1996; Menkes et al., 2002). Seasonally intensified occurrence of these phenomena are said to generate regions of enhanced upwelling and subduction that can lead to localized high productivity and biomass accumulation, respectively (Yoder et al., 1994; Archer et al., 1997). For example, Friedrichs and Hofmann (2001) documented a 60-70\% increase in chlorophyll concentration and a $400 \%$ increase in the chlorophyll contribution by diatoms associated with the passage of a TIW at $0^{\circ} \mathrm{N}, 140^{\circ} \mathrm{W}$. Vichi et al. (2008) showed that the net local effect of the waves on phytoplankton can be either positive or negative depending on several factors. Gorgues et al. (2005) demonstrated that TIWs have a net decreasing effect on Fe supply and consequently new production at the equator, contrary to Salihoglu and Hofmann (2007), who showed that the iron flux to the equatorial surface waters is underestimated in the absence of high frequency events such as TIWs and IGWs. Evans et al. (2009) concluded that generalizing TIW effects is difficult due to the variability associated with TIW intensity and season as observed in nutrient and Chl fields. It can be speculated, however, that variability in instantaneous physical and biological fluxes associated with TIW activity might differ from variability in stock variables, as was shown in the case of biological responses to another mesoscale phenomenon of eddies (Xiu et al., 2011).

Recently, two Equatorial Biocomplexity (EB) cruises conducted in December 2004 (EB04) and September 2005 (EB05) revealed large variability in nutrient concentrations as well as phytoplankton uptake rates under similar seasonal and ENSO conditions (Strutton et al., 2011; Nelson and Landry, 2011). In the 2004-2005 period, this region was influenced by the so-called Central Pacific El Niño now considered distinct from ENSO (Lee and McPhaden, 2010). The observed patterns of variability in physical and biological dynamics were suggested to originate from the passage of TIWs (Krause et al., 2011; Parker et al., 2011; Strutton et al., 2011). While Landry et al. (2011) concluded that the HNLC surface waters of the EEP in general exhibit a balance of growth and grazing processes, they also pointed at the possible local and episodic nature of $\mathrm{C}$ export in the EEP, likely linked to TIW activity. They suggested that biological fluxes must be calculated at a higher spatial and temporal resolution to estimate the relative role of production, recycling and export fluxes in the overall nutrient and $\mathrm{C}$ budgets.

The EB04 and EB05 cruises provided the much needed in situ measurements which are used to evaluate coupled physical-biogeochemical models sensitive to TIW-scale dynamics. For example, Dugdale et al. (2007) found a good agreement in mean equatorial size-fractionated phytoplankton nutrient uptake rates $\left(\rho \mathrm{NO}_{3}, \rho \mathrm{NH}_{4}, \rho \mathrm{Si}(\mathrm{OH})_{4}\right)$ between EB cruises and the CoSiNE model (Carbon, Silicon, Nitrogen Ecosystem model; Chai et al., 2002; Dugdale et al., 2002). Recently, EB cruise nutrient concentration data were also combined with ROMS model (Regional Ocean Modeling System; Wang and Chao, 2004) physical fields to calculate $\mathrm{NO}_{3}, \mathrm{Si}(\mathrm{OH})_{4}$ and $\mathrm{Fe}$ budgets in the EEP during the 2004-2005 period (Palacz et al., 2011).

In this study we use observational data to evaluate high resolution ROMS-CoSiNE model spatio-temporal patterns of variability in coincident physical and biological rate and flux measurements in the EEP, and examine the role of local and instantaneous processes in controlling the highly variable phytoplankton nutrient uptake responses to TIWs. In Sect. 2, we describe the sources of data, our modeling approach and details of statistical analyses. In Sect. 3, we first compare and discuss the differences between model and observed hydrographic conditions (Sect. 3.1), phytoplankton dynamics (Sect. 3.2 to 3.4) and patterns of spatio-temporal variability (Sect. 3.5). In Sect. 3.6, we then analyze the physical and biological responses to a series of identified model TIW events and discuss the results in the context of findings from previous related studies. In Sect. 4, we present our conclusions.

\section{Model and data}

\subsection{Coupled physical-biogeochemical model}

Model calculations are performed using the biogeochemical model CoSiNE coupled with the ROMS circulation model. This coupled model was first configured for the Pacific Ocean domain $\left(45^{\circ} \mathrm{S}\right.$ to $65^{\circ} \mathrm{N}, 99^{\circ} \mathrm{E}$ to $\left.70^{\circ} \mathrm{W}\right)$ with realistic geometry and topography by Wang and Chao (2004) at a $50 \mathrm{~km}$ spatial resolution, and later at an increased resolution of $12.5 \mathrm{~km}$ by Xiu and Chai (2010). Initialized with climatological temperature and salinity from the World Ocean Atlas (WOA) 2001 (Ocean Climate Laboratory National 
Oceanographic Data Center, 2002), the Pacific ROMS model has been forced with the climatological NCEP/NCAR reanalysis of air-sea fluxes (Kalnay et al., 1996) for several decades in order to reach quasi-equilibrium. The model is then integrated for the period of 1991 to 2010 forced with daily air-sea fluxes of heat and fresh water from the NCEP/NCAR reanalysis (Kalnay et al., 1996). The heat flux is derived from short- and long-wave radiations and sensible and latent heat fluxes calculated using the bulk formula with prescribed air temperature and relative humidity. The multiple satellite blended daily sea wind with a resolution of $0.25^{\circ}$ (Zhang et al., 2006) is used to calculate the surface wind stress based on the bulk formula of Large and Pond (1982). Detailed physical and biological model configuration can be found in Liu and Chai (2009), Chai et al. (2009), and Xiu and Chai (2010).

Here, we analyze the results from a coupled physicalbiogeochemical model at the $12.5 \mathrm{~km}$ spatial and three-day temporal resolution that is capable of resolving mesoscale features in physical circulation (Xiu et al., 2010) and biogeochemical fluxes (Xiu et al., 2011; Xiu and Chai, 2011). In this study, model domain is equal to the EEP box delineated between $140^{\circ} \mathrm{W}-110^{\circ} \mathrm{W}$ and $5^{\circ} \mathrm{S}-5^{\circ} \mathrm{N}$ (Fig. 1), but a lot of spatial averaging is done over the $1^{\circ} \mathrm{S}-1^{\circ} \mathrm{N}$ latitude band to match the area most heavily sampled during both EB cruises (Fig. 1).

The results are a combination of on-line and off-line model calculations - an approach that was validated in Palacz et al. (2011) and which allowed us to optimize the model performance specifically in the EEP region. In this study, we use on-line calculated three-day averaged net short-wave radiation flux (which is converted to light field to calculate biological production), temperature and nutrient concentration fields. These variables provide input for off-line calculated vertical light profiles, phytoplankton and zooplankton biomass, specific growth rates, nutrient uptake rates and grazing. Model equations are the same as in Chai et al. (2002). Our model results include two groups of phytoplankton, small (S1) and large phytoplankton (S2), and two groups of zooplankton, micro- (ZZ1) and mesozooplankton (ZZ2). Size-fractionated phytoplankton nutrient uptake rates $\left(\rho \mathrm{NO}_{3}, \rho \mathrm{Si}(\mathrm{OH})_{4}\right.$ and $\left.\rho \mathrm{NH}_{4}\right)$ are calculated explicitly. Total $\mathrm{N}$ uptake $\left(\rho \mathrm{NO}_{3}+\rho \mathrm{NH}_{4}\right)$ is converted into $\mathrm{C}$ units using a fixed Redfield ratio of 6.6 to estimate PP. Although there is no $\mathrm{Fe}$ component in the CoSiNE model, most nutrient and phytoplankton dynamics can be captured accurately using only Si-limitation of large phytoplankton. Model sensitivity to effects of variable Fe supply was performed implicitly by varying the light-limited photosynthesis parameter (Chai et al., 2007).

Off-line calculations offer several advantages for this modeling study. First, they are computationally less costly and more time efficient. By performing more model runs, we are able to test different model configurations and parameter values in order to simulate the EEP conditions best. For exam-

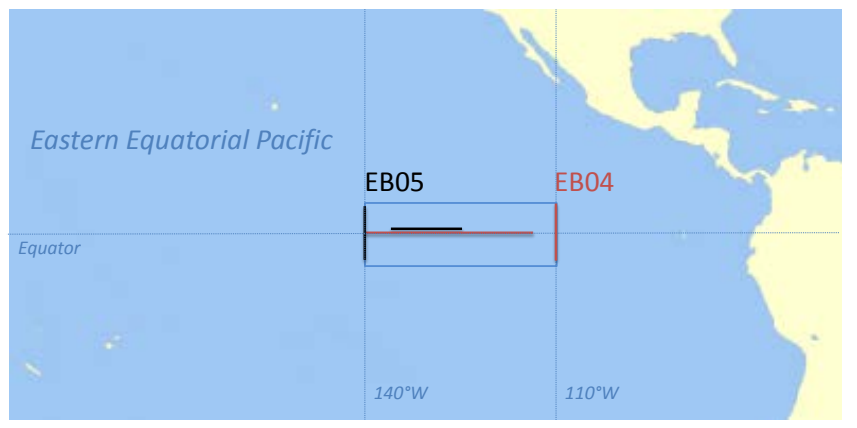

Fig. 1. Location of the eastern equatorial Pacific Ocean study area. Red lines indicate the location of EB04 cruise sampling transects from December 2004, and blue lines indicate the location of EB05 cruise sampling transects from September 2005.

ple, we distinguish between using daily-averaged and diurnal cycles of light as an energy source for phytoplankton growth. Second, we conduct series of sensitivity studies to find an optimum set of biological parameters, including $\rho \mathrm{Si}(\mathrm{OH})_{4}$ and $\rho \mathrm{NH}_{4}$ half-saturation constants, $\mathrm{Si}: \mathrm{N}$ uptake ratio and zooplankton grazing rates. While many parameters in the biological model are the same as in Chai et al. (2002), others, listed in Table 1, are modified based either on the findings of the EB project or are derived from model sensitivity runs.

An important aspect of this off-line modeling exercise is that it allowed us to "turn off" the process of advection of phytoplankton and zooplankton biomass. Growth rates, nutrient uptake rates and plankton biomass are calculated offline every hour and later averaged into three-day estimates. Considering that turnover of phytoplankton biomass is comparable to the three-day period during which two on-line variables (surface light and nutrients) are updated, we do not anticipate any large inconsistencies between on-line physical and nutrient fields and the off-line biological fields. On the other hand, this exercise enables to investigate the local and instantaneous effect of passing TIWs (or TIVs) in the absence of otherwise important processes of plankton advection considered elsewhere (e.g., Gorgues et al., 2005; Vichi et al., 2008; Evans et al., 2009).

\subsection{Cruise data}

Evaluation of the $12.5 \mathrm{~km}$ Pacific ROMS-CoSiNE nutrient cycling results is based on comparison with corresponding measurements conducted during the two EB cruises aboard the R/V Revelle, EB04 in December 2004 and EB05 in September 2005. On 10 December 2004, EB04 started observations at $5^{\circ} \mathrm{N}, 110^{\circ} \mathrm{W}$, then headed south along $110^{\circ} \mathrm{W}$ to complete a transect along the equator between $110^{\circ} \mathrm{W}$ and $140^{\circ} \mathrm{W}$ by 29 December 2004. On 8 September 2005 , EB05 commenced observations at $4^{\circ} \mathrm{N}, 140^{\circ} \mathrm{W}$, headed south along $140^{\circ} \mathrm{W}$ and then east along $0.5^{\circ} \mathrm{N}$ to about $125^{\circ} \mathrm{W}$, completing observations on 24 September 2005. 
Table 1. Optimized CoSiNE model parameters. Key model parameters used in this study are compared with the early CoSiNE model parameterization applied by Chai et al. (2002).

\begin{tabular}{lllll}
\hline CoSiNE model parameter & Symbol & This study & Chai et al. (2002) & Unit \\
\hline Light & $I$ & Diurnal cycle & Diurnal cycle & $\mathrm{W} \mathrm{m}^{-2}$ \\
$\mathrm{NH}_{4}$ inhibition for small phyto. & $\Psi_{\mathrm{S} 1}$ & 10.00 & 5.59 & $\left(\mathrm{mmol} \mathrm{m}^{-3}\right)^{-1}$ \\
$\mathrm{NH}_{4}$ inhibition for large phyto. & $\Psi_{\mathrm{S} 2}$ & 4.00 & 5.59 & $\left(\mathrm{mmol} \mathrm{m}^{-3}\right)^{-1}$ \\
Half-saturation for $\rho \mathrm{NH}_{4}$ by small phyto. & $K_{\mathrm{S} 1 \_\mathrm{NH}_{4}}$ & 0.10 & 0.05 & $\mathrm{mmol} \mathrm{m}^{-3}$ \\
Half-saturation for $\rho \mathrm{NH}_{4}$ by large phyto. & $K_{\mathrm{S} 2 \mathrm{NH}_{4}}$ & None & 1.00 & $\mathrm{mmol} \mathrm{m}^{-3}$ \\
Half-saturation for $\rho \mathrm{NO}_{3}$ by small phyto. & $K_{\mathrm{S} 1 \mathrm{NO}_{3}}$ & 0.50 & 0.50 & $\mathrm{mmol} \mathrm{m}^{-3}$ \\
Half-saturation for $\rho \mathrm{NO}_{3}$ by large phyto. & $K_{\mathrm{S} 2 \_\mathrm{NO}_{3}}$ & 1.00 & 0.50 & $\mathrm{mmol} \mathrm{m}^{-3}$ \\
Half-saturation for $\rho \mathrm{Si}(\mathrm{OH})_{4}$ & $K_{\mathrm{Si}(\mathrm{OH})_{4}}$ & 3.50 & 3.00 & $\mathrm{mmol} \mathrm{m}^{-3}$ \\
Large phyto. Si $: \mathrm{N}$ uptake ratio & $\mathrm{Si}: \mathrm{N}$ & Dynamic $>1$ & 1.00 & - \\
Max specific growth rate of small phyto. & $\mu \mathrm{S} 1_{\mathrm{max}}$ & 2.00 & 2.00 & $\mathrm{~d}^{-1}$ \\
Max specific growth rate of large phyto. & $\mu \mathrm{S} 2_{\mathrm{max}}$ & 2.50 & 3.00 & $\mathrm{~d}^{-1}$ \\
\hline
\end{tabular}

Approximate cruise transects are showed in Fig. 1. Details of station locations and hydrographic conditions from both cruises can be found in Strutton et al. (2011). Sampling and data analysis methods of $\rho \mathrm{NO}_{3}$ and $\rho \mathrm{NH}_{4}$ measurements are described in Dugdale et al. (2007) and Parker et al. (2011). Krause et al. (2011) give a detailed procedure for calculating $\rho \mathrm{Si}(\mathrm{OH})_{4}$ rates, while Balch et al. (2011) provide information on estimating total community and size-fractionated $\mathrm{C}$ fixation rates.

\subsection{Statistical analysis}

The skill of the Pacific ROMS-CoSiNE model is assessed using comparisons with data collected in situ during EB cruises. Apart from mean and variability estimates, we calculate model bias $(\mathrm{B}$; representing the difference between the means of the two fields) and the centered pattern root mean square difference $\left(\mathrm{RMSD}_{\mathrm{cp}}\right.$; equivalent to an unbiased RMSD representing the differences in the variability of the two fields). Combining B and $\mathrm{RMSD}_{\mathrm{cp}}$, we obtain the total RMSD (RMSD tot ) which provides a valuable overall comparison of model and data fields (Campbell et al., 2002; Friedrichs et al., 2009).

Model-data comparison of nutrient uptake rates is illustrated by means of a target diagram (Jolliff et al., 2009). Target diagrams are used to visualize $\mathrm{B}, \mathrm{RMSD}_{\mathrm{cp}}$ and $\mathrm{RMSD}_{\text {tot }}$ on a single plot. On the target diagram, these statistical metrics are normalized by standard deviation of the data $\left(\sigma_{\mathrm{d}}\right)$. On this plot, normalized $\mathrm{B}$ is on the $\mathrm{y}$-axis and normalized $\mathrm{RMSD}_{\mathrm{cp}}$ is on the $\mathrm{x}$-axis. Concentric circles represent normalized $\mathrm{RMSD}_{\text {tot }}$ isolines with the solid circle representing the normalized deviation of the data. If model RMSD tot $_{\text {ex- }}$ ceeds the standard deviation of observations, i.e., $\mathrm{RMSD}_{\text {tot }}>$ 1 , then the model is showing less skill than does the mean of observations.

\section{Results and discussion}

In this section, we describe and discuss patterns of variability in model phytoplankton nutrient and $\mathrm{C}$ uptake in the EEP during 2004-2005. First, we verify the capability and skill of the Pacific ROMS-CoSiNE model to reproduce the hydrographic conditions ( $T, \mathrm{O}_{2}$, nutrient concentration fields) encountered during the EB04 and EB05 cruises (Strutton et al., 2011). Second, we compare the EB cruise and modeled biological environment of the EEP, including phytoplankton growth and nutrient uptake rates, biomass and species composition. Third, we present two-year temporal and spatiotemporal patterns of nutrient and $\mathrm{C}$ uptake rates and compare them with in situ and satellite model estimates when available. Fourth, we describe and discuss patterns of variability in the model physical and biological responses to several identified TIW events. Considering only a two-year period of analysis, we do not analyze the effects of lower frequency modulations. However, we acknowledge that the biological and physical conditions in this region were affected by the Central Pacific Niño that was reported during the 2004-2005 period (Lee and McPhaden, 2010).

\subsection{Hydrographic conditions}

Fig. 2 reveals that there is a wide range of $T$ in the top $150 \mathrm{~m}$ of the water column (Fig. 2a), suggesting a steep thermocline that is indicative of a strong cold water upwelling in the EUZ. There is a high and statistically significant linear correlation between in situ measured and modeled $T$ during December $2004(r=0.97, p<0.01)$ and September 2005 $(r=0.91, p<0.01)$. A small but consistent negative bias indicates that the model tends to slightly underestimate $T$ with respect to both EB04 (bias of $-1.53^{\circ} \mathrm{C}$ ) and EB05 (bias of $-2.71^{\circ} \mathrm{C}$ ) observations. The bias is larger in the lower range of $T$, corresponding to shallower depths (Fig. 2a). Nevertheless, this bias, describing the difference between the means of two datasets, does not contribute much to $\mathrm{RMSD}_{\text {tot }}$. The 

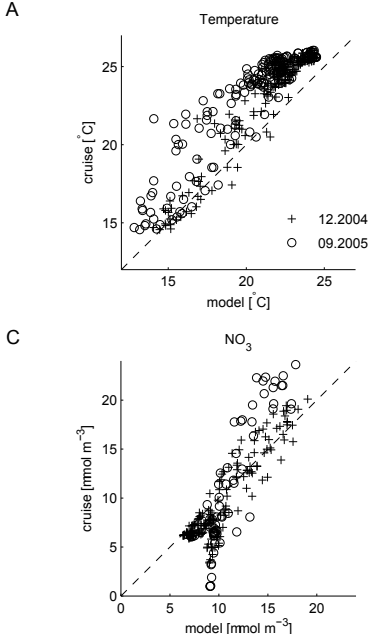

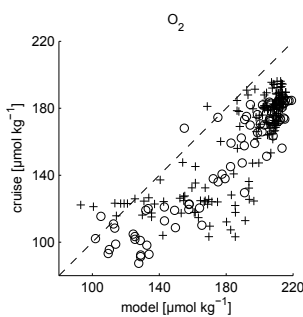

D

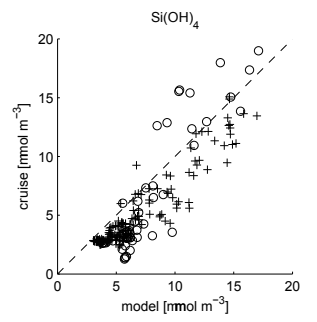

Fig. 2. Collection of scatter plots representing in situ and the modeled hydrographic conditions for the depth range of $0-150 \mathrm{~m}$ and along two longitude lines $\left(140^{\circ} \mathrm{W}\right.$ and $\left.110^{\circ} \mathrm{W}\right)$. The model results are meridional averages from $1^{\circ} \mathrm{S}-1^{\circ} \mathrm{N}$, and 15-day or 9-day time averages (roughly corresponding to the length of EB04 and EB05 equatorial transects (Strutton et al., 2011)). December 2004 data (+) and September 2005 (o) are plotted separately. The dashed diagonal line in each scatter plot is the $1: 1$ perfect model-data fit line. (A) $T\left({ }^{\circ} \mathrm{C}\right),(\mathbf{B}) \mathrm{O}_{2}\left(\mu \mathrm{mol} \mathrm{O} \mathrm{kg}^{-1}\right),(\mathbf{C}) \mathrm{NO}_{3}\left(\mathrm{mmol} \mathrm{N} \mathrm{m}^{-3}\right)$, and (D) $\mathrm{Si}(\mathrm{OH})_{4}\left(\mathrm{mmol} \mathrm{Si} \mathrm{m}^{-3}\right)$.

$\mathrm{RMSD}_{\mathrm{cp}}$, or the unbiased RMSD, which is used to assess the differences in variability, is relatively low for $T$ (0.95 and $1.35^{\circ} \mathrm{C}$ in 2004 and 2005 , respectively). This good overall relationship is also evident in the domain-average mean and standard deviation model and data estimates (Table 2).

The model also does well when simulating the distribution of $\mathrm{O}_{2}$ (Fig. 2b), a proxy for both upwelling of deep waters and biological remineralization activity. There is a high correlation between model and data, especially in September 2005 ( $r=0.93, p<0.01)$. The model simulates the observed variability very well, with a small difference in amplitude of variability between the two years (Fig. 2b and Table 2). A consistent positive bias present in the model is more visible than in the case of $T$ (compare Fig. 2b with $2 \mathrm{a}$ ), but shows little statistical difference between 2004 and 2005 ( 29.0 vs. $29.3 \mathrm{mg} \mathrm{O}_{2} \mathrm{~m}^{-3}$ ). Fig. $2 \mathrm{~b}$ reveals that the largest bias occurs at mid $\mathrm{O}_{2}$ range.

$\mathrm{NO}_{3}$ and $\mathrm{Si}(\mathrm{OH})_{4}$ concentrations are compared in Fig. 2c and Fig. 2d, respectively. Both relationships are very highly correlated and statistically significant at the $99 \%$ level $(r>$ 0.90). We note that model $\mathrm{NO}_{3}$ is overestimated in its lower values (at the surface) but underestimated it its higher values (below the euphotic zone). This is likely related to the bias in $T$ identified in Fig. $2 \mathrm{a}$. The $\sigma_{\mathrm{m}} / \sigma_{\mathrm{d}}$ of $\mathrm{NO}_{3}$ reveals that the model also underestimates the amplitude of variability, more so in September 2005 than in December 2004 (0.42 vs. 0.77). Table 2 confirms that while the mean model and data fields

are very similar, the model $\mathrm{NO}_{3}$ variability (standard deviation) is underestimated relative to other hydrographic factors.

Small positive model bias in surface $\mathrm{NO}_{3}$ and low $\mathrm{NO}_{3}$ variability is unlikely to create a positive bias in phytoplankton new production. This is because of predominant $\mathrm{Si}-$ Fe co-limitation of large phytoplankton (Brzezinski et al., 2011). In the model it is assumed that $\mathrm{Si}(\mathrm{OH})_{4}$ availability plays the main role in controlling large phytoplankton growth and new production because they share the functional properties of diatoms.

A very good model-data comparison of $\mathrm{Si}(\mathrm{OH})_{4}$ and other hydrographic parameters (Table 2 and Fig. 2), provides confidence in Pacific ROMS-CoSiNE's ability to simulate the characteristic low $\mathrm{Si}(\mathrm{OH})_{4}$ HNLC conditions of the EEP region, and justifies the use of our model approach to perform the biological rate calculations described in the next sections.

\subsection{Nutrient and $\mathrm{C}$ uptake rates}

The model is able to capture the mean state of all biological rates in the EEP domain, but in general performs better in December 2004 (Table 2). The only visible large discrepancy between model and data occurs for $\rho \mathrm{NH}_{4}$ during September 2005. There is a consistent positive bias associated with $\rho \mathrm{Si}(\mathrm{OH})_{4}$ that originates from the fact that all large phytoplankton in the model take up $\mathrm{Si}(\mathrm{OH})_{4}$, while in the field diatoms comprise only a fraction of that population (Parker et al., 2011; Taylor et al., 2011). One might suspect that overestimated model $\rho \mathrm{Si}(\mathrm{OH})_{4}$ would lead to overestimated PP. However, mean model PP is in very good agreement with EB measurements (Table 2). Most model rate estimates are within a factor of two from the mean in situ measurements. Such a good box-average agreement is the basis for positive model performance evaluation.

Additionally, in Fig. 3 we use a target diagram to illustrate the normalized biased and unbiased statistical metrics used to compare ROMS-CoSiNE and EB macronutrient and $\mathrm{C}$ uptake rates, as well as satellite-derived PP estimates. We conclude that the spatial variability in uptake rates is modeled reasonably well, with the exception of $\rho \mathrm{Si}(\mathrm{OH})_{4}$ that was shown to be overestimated for reasons discussed above. It is clear that there are large year to year discrepancies in the model bias. On the other hand, the unbiased $\mathrm{RMSD}_{\mathrm{cp}}$ shows no such trend, and remains relatively low for both uptake rate estimates.

Results shown in Fig. 3 also reveal a certain paradox by which the model provides a consistently good representation of PP over the two year sampling periods, but less satisfying results of $\rho \mathrm{Si}(\mathrm{OH})_{4}, \rho \mathrm{NO}_{3}$ and $\rho \mathrm{NH}_{4}$ in 2005 than in 2004. If total $\mathrm{C}$ uptake by phytoplankton is linked to the uptake of total $\mathrm{N}$ by means of a constant Redfield ratio (Arrigo, 2005, and references therein) as it is done in the ROMSCoSiNE model $\left(\mathrm{PP}=\right.$ Redfield ratio $\left.\times\left(\rho \mathrm{NO}_{3}+\rho \mathrm{NH}_{4}\right)\right)$, then we would expect no discrepancy in the model bias and variability of $\mathrm{N}$ and $\mathrm{C}$ uptake between the two time periods. 
Table 2. The 2004-2005 model-data comparison of monthly and domain average $\left(1^{\circ} \mathrm{S}-1^{\circ} \mathrm{N}\right.$ and $\left.140^{\circ} \mathrm{W}-110^{\circ} \mathrm{W}\right)$ hydrographic conditions $\left(T, \mathrm{O}_{2}, \mathrm{NO}_{3}, \mathrm{Si}(\mathrm{OH})_{4}\right)$, depth-integrated total phytoplankton nutrient $\left(\rho \mathrm{NO}_{3}, \rho \mathrm{NH}_{4}, \rho \mathrm{Si}(\mathrm{OH})_{4}\right)$ and $\mathrm{C}(\mathrm{PP})$ uptake rates, total phytoplankton specific growth rates $(\mu)$ and biomass $(S)$, as well as total and size-fractionated $f$-ratios. Mean and standard deviations come from the alongequatorial profiles between $140^{\circ} \mathrm{W}$ and $110^{\circ} \mathrm{W}$. PP data from Balch et al. (2011), $\rho \mathrm{NO}_{3}$ and $\rho \mathrm{NH}_{4}$ from Parker et al. (2011), and $\rho \mathrm{Si}(\mathrm{OH})_{4}$ from Krause et al. (2011), $\mu$ data from Selph et al. (2011) and biomass estimates from Balch et al. (2011). Cruise f-ratios were calculated by Parker et al. (2011). Depth integration is over the top $75 \mathrm{~m}$ depth, beneath which there is little nutrient uptake by phytoplankton (Aufdenkampe et al., 2002; Parker et al., 2011).

\begin{tabular}{|c|c|c|c|c|c|}
\hline \multirow[b]{2}{*}{ Variable } & \multirow[b]{2}{*}{ Unit } & \multicolumn{2}{|c|}{ December 2004} & \multicolumn{2}{|c|}{ September 2005} \\
\hline & & EB data & Model & EB data & Model \\
\hline$T$ & $\left({ }^{\circ} \mathrm{C}\right)$ & $23.1 \pm 3.29$ & $21.6 \pm 2.76$ & $22.0 \pm 4.14$ & $20.5 \pm 2.52$ \\
\hline $\mathrm{O}_{2}$ & $\left(\mathrm{mg} \mathrm{O}_{2} \mathrm{~m}^{-3}\right)$ & $161 \pm 27.9$ & $190 \pm 28.2$ & $148 \pm 34.6$ & $177 \pm 37.2$ \\
\hline $\mathrm{NO}_{3}$ & $\left(\mathrm{mmol} \mathrm{Nm} \mathrm{m}^{-3}\right)$ & $9.62 \pm 4.18$ & $10.3 \pm 3.21$ & $11.4 \pm 7.05$ & $11.4 \pm 2.97$ \\
\hline $\mathrm{Si}(\mathrm{OH})_{4}$ & $\left(\mathrm{mmol} \mathrm{Si} \mathrm{m}{ }^{-3}\right)$ & $5.04 \pm 3.09$ & $6.68 \pm 3.48$ & $6.15 \pm 3.07$ & $7.64 \pm 3.20$ \\
\hline PP & $\left(\mathrm{mmolCm} \mathrm{m}^{-2} \mathrm{~d}^{-1}\right)$ & $62.4 \pm 9.2$ & $53.1 \pm 5.5$ & $59.3 \pm 18.6$ & $64.1 \pm 6.2$ \\
\hline$\rho \mathrm{NO}_{3}$ & $\left(\mathrm{mmol} \mathrm{N} \mathrm{m} \mathrm{m}^{-2} \mathrm{~d}^{-1}\right)$ & $3.59 \pm 1.32$ & $2.46 \pm 0.63$ & $4.17 \pm 1.82$ & $2.67 \pm 0.76$ \\
\hline$\rho \mathrm{Si}(\mathrm{OH})_{4}$ & $\left(\mathrm{mmol} \mathrm{Si} \mathrm{m}{ }^{-2} \mathrm{~d}^{-1}\right)$ & $1.70 \pm 0.56$ & $3.18 \pm 1.02$ & $1.23 \pm 0.61$ & $3.58 \pm 1.25$ \\
\hline$\rho \mathrm{NH}_{4}$ & $\left(\mathrm{mmolN} \mathrm{m} \mathrm{m}^{-2} \mathrm{~d}^{-1}\right)$ & $7.94 \pm 5.22$ & $5.58 \pm 0.88$ & $17.1 \pm 3.7$ & $7.05 \pm 0.78$ \\
\hline$\mu$ & $\left(d^{-1}\right)$ & $0.53 \pm 0.11$ & $0.45 \pm 0.03$ & $0.39 \pm 0.11$ & $0.48 \pm 0.03$ \\
\hline$S$ & $\left(\mathrm{mgChl} \mathrm{m}^{-2}\right)$ & $26.5 \pm 3.4$ & $28.4 \pm 4.6$ & $32.4 \pm 5.1$ & $32.1 \pm 4.9$ \\
\hline f-ratio (S1) & & 0.38 & 0.25 & 0.10 & 0.22 \\
\hline f-ratio (S2) & & 0.34 & 0.39 & 0.33 & 0.36 \\
\hline f-ratio (total) & & 0.28 & 0.31 & 0.16 & 0.27 \\
\hline
\end{tabular}

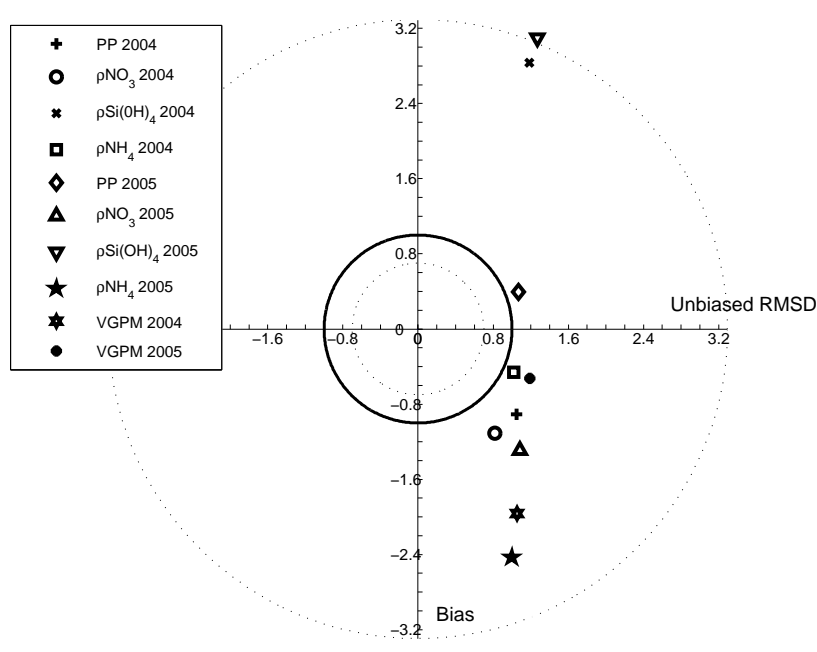

Fig. 3. Target diagram of PP and nutrient uptake rates in the EEP during 2004-2005. Diagram shows the normalized B and $\mathrm{RMSD}_{\mathrm{cp}}$ (unbiased RMSD) for the model PP, $\rho \mathrm{NO}_{3}, \rho \mathrm{Si}(\mathrm{OH})_{4}, \rho \mathrm{NH}_{4}$ and satellite VGPM (Vertically Generalized Production Model) PP estimates relative to the EB observations from December 2004 and September 2005. Concentric circles represent RMSD tot isolines.

C uptake during EB was measured independently (Balch et al., 2011) and is prone to a different sampling error than $\rho \mathrm{NO}_{3}$ and $\rho \mathrm{NH}_{4}$ (Parker et al., 2011). However, both methods of calculating uptake rates have been performed side by side in the equatorial Pacific during previous cruises and are unlikely to carry a measurement error large enough to explain this difference. Thus, it is likely that the model assumption of a constant Redfield ratio needs to be reevaluated in order to more accurately capture the dynamics of phytoplankton $\mathrm{C}$ and nutrient uptake rates in the EEP.

In order to fully inspect the model skill in describing the phytoplankton nutrient uptake dynamics in the EEP, we further verify how the model captures the mean phytoplankton specific growth rate $(\mu)$ and phytoplankton biomass $(S)$, the product of which determines the total nutrient uptake rates.

\subsection{Specific growth rates and biomass}

The analysis of EEP box mean $\mu$ and $S$ is particularly useful in illustrating why the total $\mathrm{N}$ and $\mathrm{C}$ uptake rates are well modeled under December 2004 but less so under September 2005 conditions (Fig. 3 and Table 2). The mean total phytoplankton $\mu$, calculated on the basis of a seawater dilution method (Selph et al., 2011), equals $0.53 \pm 0.11 \mathrm{~d}^{-1}$ in December 2004 and is well matched and only slightly underestimated by the model mean equal to $0.45 \pm 0.03 \mathrm{~d}^{-1}$ (Table 2). However, in September 2005, the model overestimates $\mu$ despite displaying much lower standard deviation associated with spatial variability (Table 2). At the same time, $S$, defined as total amount of $\mathrm{Chl}$ pigment in cells $>0.45 \mu \mathrm{m}$ in diameter, was estimated at $26.5 \pm 3.4 \mathrm{mg} \mathrm{Chl} \mathrm{m}^{-2}$ during EB04 (Balch et al., 2011). This is in very good agreement with the modeled $28.4 \pm 4.6 \mathrm{mg} \mathrm{Chl} \mathrm{m}^{-2}$. The comparison is 
even better in September 2005 when the model $S$ matches well both in terms of the mean and variability (Table 2).

The conclusions derived from these results shed more light on the year-to-year discrepancy in model performance in simulating total nutrient and $\mathrm{C}$ uptake rates. It appears that the model does a very good job in capturing the mean state of total phytoplankton biological production described by PP, total $\mu$ and $S$. However, when looking at $\rho \mathrm{NO}_{3}, \rho \mathrm{NH}_{4}$ and $\rho \mathrm{Si}(\mathrm{OH})_{4}$, we need to consider what the species composition of the phytoplankton community looks like. The model, which only uses a simple two phytoplankton group setup and assumes that all large phytoplankton have the same functional behavior as diatoms, does not simulate all phytoplankton growth dynamics well, as revealed by the discrepancy in 2004 and $2005 \rho \mathrm{NH}_{4}$ or the consistent positive bias in $\rho \mathrm{Si}(\mathrm{OH})_{4}$. In the following section we explore the possible role of this limitation in preventing the model from fully resolving the patterns of variability in biological production in the EEP.

\subsection{Phytoplankton species composition}

The numerous studies integrated within the EB project reveal a very dynamic phytoplankton community with relative abundances of several autotrophic functional groups shifting on small spatial and temporal scales (Selph et al., 2011; Stukel et al., 2011; Taylor et al., 2011). Parker et al. (2011) speculated that the role of diatoms in total $\rho \mathrm{NO}_{3}$ could be several times higher than their biomass contribution $(<10 \%)$. At the same time, they pointed out the importance of accounting for large dinoflagellates, which obtain their $\mathrm{N}$ from both mixotrophy and $\rho \mathrm{NO}_{3}$. Large dinoflagellates have a big share in new production while constituting for much of the larger size fraction of phytoplankton biomass. Since the CoSiNE model only takes into account two functional types of phytoplankton, we cannot distinguish between diatoms and dinoflagellates in the large phytoplankton size fraction. However, through a comparison of large phytoplankton cell biomass obtained from size-fractionated $\mathrm{Chl}$ measurements (Balch et al., 2011) and pigment-specific diatom concentration (Taylor et al., 2011), we can comment on the role of diatoms in nutrient uptake relative to their biomass, and place this discussion in the context of the disparate September $2005 \mathrm{~N}, \mathrm{Si}$ and C flux estimates discussed above.

While diatoms comprise on average only $6.5 \%$ of the total autotrophic community in the study periods (Taylor et al., 2011), Parker et al. (2011) documented that diatoms make up between 13 and $37 \%$ of the total phytoplankton community. However, at several biological "hotspots" along the equator, they constituted 37 and $45 \%$ of the $>5 \mu$ m phytoplankton size group in December 2004 and September 2005, respectively (Parker et al., 2011). These hotspots, partly associated with strong upwelling close to the leading or trailing edge of a TIW (Parker et al., 2011, their figure 9), also strongly affect $\rho \mathrm{NO}_{3}$ and $\rho \mathrm{Si}(\mathrm{OH})_{4}$ variability along the equator (Parker et al., 2011; Krause et al., 2011). In the model, large phytoplankton biomass oscillates between 24 and $44 \%$ of total biomass across the entire 2004-2005 period but is on average equal to $42 \%$ during the two months when EB cruises took place. This estimate is higher than $6.5 \%$ diatom biomass contribution measured in the field, and also an overestimate with respect to the $20-30 \%$ contribution of the $>3 \mu \mathrm{m}$ phytoplankton biomass reported by Balch et al. (2011).

Large $(>5 \mu \mathrm{m})$ dinoflagellates, which do not have an Si-requirement for growth and thus do not obscure the $\rho \mathrm{Si}(\mathrm{OH})_{4}$ model-data comparison, can have a large contribution to total $\rho \mathrm{NO}_{3}$ whenever their $\mathrm{N}$ demand is not satisfied by phagotrophy (Stukel et al., 2011). Assuming that diatoms compete for both $\mathrm{NO}_{3}$ and $\mathrm{NH}_{4}$, as it is also assumed in the model, Parker et al. (2011) estimated that dinoflagellates account on average for $55 \%$ of $\rho \mathrm{NO}_{3}$ in the $>5 \mu \mathrm{m}$ fraction. The EB cruises reported that diatoms on average would account for $45 \%$ of $\rho \mathrm{NO}_{3}$ (Parker et al., 2011). This is in good agreement with the model large phytoplankton $\rho \mathrm{NO}_{3}$ of $48 \%$ in December 2004, and $50 \%$ in September 2005 . We also find a good agreement between model diatom f-ratios and the $>5 \mu \mathrm{m}$ size-fractionated f-ratio from EB04 and EB05 (Table 2). Diatom contribution to PP in the model is $40 \%$ in December 2004 and $37 \%$ in September 2005. Landry et al. (2011) calculated that large eukaryotic phytoplankton constituted between 15 and $62 \%$ of primary production in the EEP, with diatoms contributing on average $18 \%$ of total autotrophic production. This indicates minor fluctuations in the otherwise overestimated role of model diatoms in PP variability in the EEP.

In order to understand the discrepancy between the modeled and the observed nutrient and $\mathrm{C}$ uptake rates, it is important to mention the significant differences in phytoplankton composition reported during EB cruises (Selph et al., 2011; Stukel et al., 2011; Taylor et al., 2011). In September 2005, contribution of Prochloroccocus towards total autotrophic biomass increased by more than twofold (Taylor et al., 2011). These small cells rely on $\mathrm{NH}_{4}$ as their principal source of $\mathrm{N}$ for growth, and their elevated biomass enhanced $\rho \mathrm{NH}_{4}$ more than twofold during EB05 (Table 2; Parker et al., 2011). $\rho \mathrm{NO}_{3}$ by large phytoplankton increased as well (Parker et al., 2011) but without a concomitant elevation in $\rho \mathrm{Si}(\mathrm{OH})_{4}$ (Krause et al., 2011). Parker et al. (2011) demonstrated that in December $2004 \rho \mathrm{NO}_{3}$ by cells $>5 \mu \mathrm{m}$ was equal or greater than the estimated diatom demand for $\mathrm{N}$. In September 2005, it was much lower than the diatom demand, suggesting an increase in relative contribution of large dinoflagellates (that do not take up $\mathrm{Si}$ ) to $\rho \mathrm{NO}_{3}$. At the same time, in situ observations reported only a small change in the EEP mean PP relative to EB04 (Balch et al., 2011).

We conclude that while the CoSiNE model simulates the overall phytoplankton nutrient uptake dynamics well, its size-fractionated nutrient uptake is not always adequate to represent the interaction between shifts in phytoplankton species composition and nutrient and $\mathrm{C}$ uptake rates. 
Regardless, overestimated role of diatoms and $\rho \mathrm{Si}(\mathrm{OH})_{4}$ does not seem to affect the model-data PP comparison significantly, at least under the conditions measured during EB cruises.

\subsection{Patterns of spatio-temporal variability}

In Fig. 4a we reveal that the EEP-averaged PP oscillates strongly on intraseasonal time scales, with visible low frequency modulations of the variability amplitude. The 20042005 mean PP equals $54.7 \mathrm{mmol} \mathrm{C} \mathrm{m}^{-2} \mathrm{~d}^{-1}$, with a minimum of 37.8 and a maximum of $68.3 \mathrm{mmol} \mathrm{C} \mathrm{m}^{-2} \mathrm{~d}^{-1}$. Mean $\mathrm{NOO}_{3}$ is estimated at $2.49 \mathrm{mmol} \mathrm{N} \mathrm{m}^{-2} \mathrm{~d}^{-1}$ but varies by more than a factor of three across the time period, from a minimum of 1.19 to a maximum of $4.12 \mathrm{mmol} \mathrm{N} \mathrm{m}^{-2} \mathrm{~d}^{-1}$ (Fig. 4b). $\rho \mathrm{Si}(\mathrm{OH})_{4}$ has a minimum value of $2.07 \mathrm{mmol} \mathrm{Si} \mathrm{m}^{-2} \mathrm{~d}^{-1}$ and a maximum of $5.37 \mathrm{mmol} \mathrm{Si} \mathrm{m}^{-2} \mathrm{~d}^{-1}$ (Fig. 4c). Mean $\rho \mathrm{Si}(\mathrm{OH})_{4}$ equals $3.65 \mathrm{mmol} \mathrm{Si} \mathrm{m}^{-2} \mathrm{~d}^{-1}$.

The September 2005 mismatch between mean model and data $\rho \mathrm{NH}_{4}$, attributed to a twofold increase in Prochloroccocus abundance (Parker et al., 2011; Taylor et al., 2011), is now better explained by a relatively low $\rho \mathrm{NH}_{4}$ variability in the EEP across the two year period (Fig. 4d). The 2004-2005 model mean $\rho \mathrm{NH}_{4}$ is $5.81 \mathrm{mmol} \mathrm{N} \mathrm{m}^{-2} \mathrm{~d}^{-1}$, with the maximum domain average uptake rate of $7.66 \mathrm{mmol} \mathrm{N} \mathrm{m}^{-2} \mathrm{~d}^{-1}$. $\rho \mathrm{NH}_{4}$ data presented by Parker et al. (2011) are in the range of values reported from the JGOFS EqPac studies (Pena et al., 1994; McCarthy et al., 1996). However, Parker et al. (2011) admit that their EB $\rho \mathrm{NH}_{4}$ measurements had limitations originating from the need for ${ }^{15} \mathrm{~N}$ enrichment to stimulate any $\rho \mathrm{NH}_{4}$ under very low ambient $\mathrm{NH}_{4}$ concentrations in the collected water samples. Such an interpretation of overestimated in situ $\rho \mathrm{NH}_{4}$ is consistent with the results of the theoretical calculations of $\mathrm{C}$ uptake derived from total $\mathrm{N}$ using a 6.6-7.3 Redfield ratio range conversion. The observed high $\rho \mathrm{NH}_{4}$ would require $\mathrm{C}$ uptake much higher than the PP measured in situ (Balch et al., 2011), which however is in good agreement with our model PP estimates (Figs. 3 and 4 , Table 2).

It is difficult to constrain $\rho \mathrm{NH}_{4}$ in the model because of two reasons. First, rapid turnover time of $\mathrm{NH}_{4}$, on an order of $1 \mathrm{~h}$, makes modeling $\mathrm{NH}_{4}$ dynamics very difficult. Second, the major source of $\mathrm{NH}_{4}$ is from regeneration processes that depend on zooplankton biomass, another biological factor that is difficult to constrain and capture in the model. Regardless of the error associated with the $\rho \mathrm{NH}_{4}$ estimates, in situ and model alike, availability of $\mathrm{NH}_{4}$ is not expected to limit phytoplankton growth and thus is not a deterministic factor in regulating $\mathrm{C}$ cycling in the EEP. On the other hand, noting the discrepancies in model and in situ $\rho \mathrm{NH}_{4}$ estimates is crucial to understanding when and how it is possible to obtain very similar values of PP under different nutrient limiting conditions implicitly described by $\rho \mathrm{Si}(\mathrm{OH})_{4}$ (e.g., in September 2005, Fig. 4a vs. Fig. 4c).

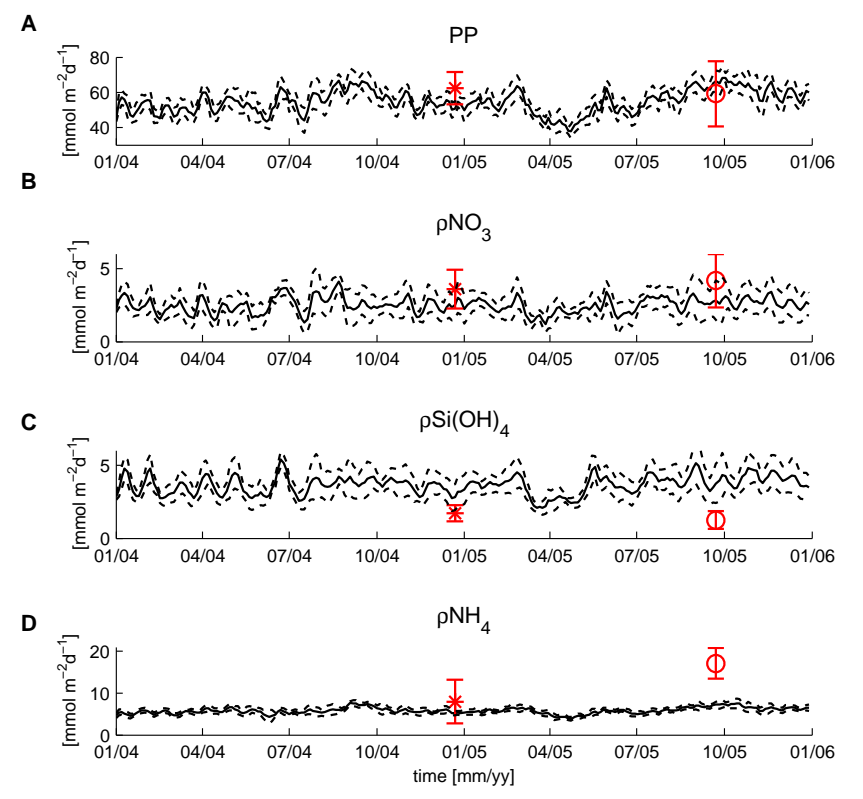

Fig. 4. Model time series of carbon and nutrient uptake rates in the EEP during 2004-2005. Results are depth-integrated and areaaveraged. Solid lines are the box means and dashed lines are $1 \sigma$ around the mean. Cruise data are from December 2004 (*) and September 2005 (o). The length of red horizontal lines on top and bottom of cruise estimates indicates the length of equatorial transects in days, while the length of vertical red lines around cruise estimates corresponds to $1 \sigma$ around the cruise EEP mean. (A) PP $\left(\mathrm{mmol} \mathrm{C} \mathrm{m}{ }^{-2} \mathrm{~d}^{-1}\right)$, (B) $\rho \mathrm{NO}_{3}\left(\mathrm{mmol} \mathrm{N} \mathrm{m}^{-2} \mathrm{~d}^{-1}\right),(\mathbf{C}) \rho \mathrm{Si}(\mathrm{OH})_{4}$ $\left(\mathrm{mmol} \mathrm{Si} \mathrm{m}{ }^{-2} \mathrm{~d}^{-1}\right)$, and (D) $\rho \mathrm{NH}_{4}\left(\mathrm{mmol} \mathrm{N} \mathrm{m}^{-2} \mathrm{~d}^{-1}\right)$.

Results presented in Fig. 4 address an important issue of how much vital information about temporal variability in phytoplankton and nutrient dynamics remains unaccounted for when comparing results from consecutive cruises substantially separated in time. In absence of in situ time series of biological production, in Fig. 5 we compare the modeled three-day average PP with the remote-sensing-derived eightday composite net primary production (NPP) from two Vertically Generalized Production Models (VGPMs), standard and Eppley-modified, and the updated C-based Production Model (CbPM) (http://www.science.oregonstate.edu/ocean. productivity/). NPP from VGPMs is a function of Chl, available light, and the photosynthetic efficiency (Behrenfeld and Falkowski, 1997). The CbPM relates NPP to phytoplankton $\mathrm{C}$ biomass and $\mu$ by retrieving information about particle backscatter and absorption (Westberry et al., 2008). In general, the mean and variability of the modeled PP are in the middle of the range of values obtained from the three satellite-derived NPP estimates. The amplitude of CbPM variability is close in line with the modeled one, though its mean value is higher than that of ROMS-CoSiNE. The two VGPMs are visibly lower in both their mean and range of variability. A similar discrepancy between in situ and satellite PP estimates was noted by McClain et al. (2002). 


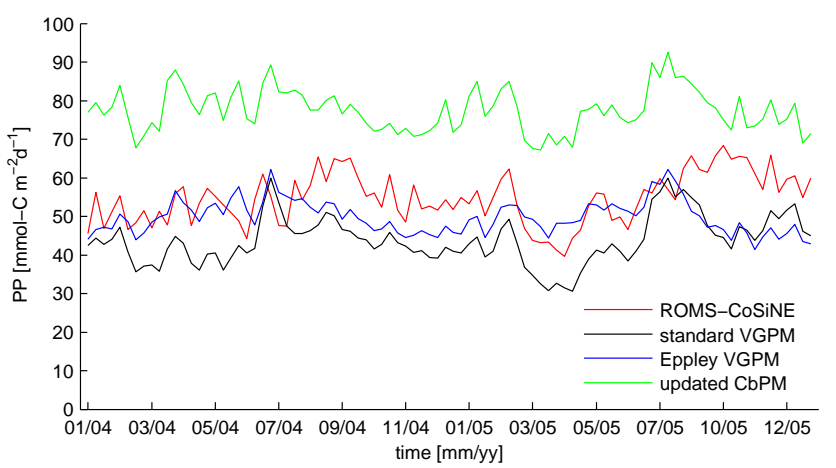

Fig. 5. 2004-2005 time series comparison of ROMS-CoSiNE model primary productivity (red line) with satellite-derived estimates of productivity from the standard VGPM (black line) result, Eppley-modified VGPM result (blue line) and the updated CbPM result (green line). All data are averaged over the EEP region. Satellite data come from http://www.science.oregonstate.edu/ ocean.productivity/. See text for a detailed description of satellite model PP algorithms.

While it is possible that ROMS-CoSiNE overestimates PP, its mean value is closer to the EB cruise measurements than the VGPM one (Fig. 3). The most significant difference in model and satellite PP time series is in Fall 2005 when the elevated PP values persist much longer and are of greater magnitude in the CoSiNE model. We suspect that the difference could be attributed to a relatively higher small phytoplankton population seen in the model during October and November 2005, also reported during the EB05 cruise (Parker et al., 2011). Blooms of small phytoplankton, as indicated by high Prochloroccocus biomass during EB05, typically occur below the surface (Selph et al., 2011), and it is possible that the satellite VGPM model of PP does not take this into account. Even though the VGPM model attempts to estimate depthintegrated and not only surface PP, its algorithm is inherently dependent on the estimates of surface optical properties predominantly. A longer time series comparison would help answer the question of whether these results provide evidence for any consistent bias in satellite estimates of PP, and how much could be attributed to model uncertainty (Friedrichs et al., 2009).

In Fig. 6 we extend the model-satellite (standard VGPM) comparison onto the spatio-temporal patterns of variability in PP. Both the $1^{\circ} \mathrm{S}-1^{\circ} \mathrm{N}$ and the $1-3^{\circ} \mathrm{N}$ area-averaged timelongitude plots reveal a good general agreement. At first glance, the model seems to capture the key features such as a westward decreasing gradient in PP consistent with westward decreasing nutrients and Chl distribution (Jiang et al., 2003; Wang et al., 2006; Kaupp et al., 2011), seasonal variability (Dandonneau et al., 2004; Wang et al., 2006) and intraseasonal variability likely attributed to passing TIWs (e.g., Strutton et al., 2011). There is a consistent positive bias in model PP indicated by higher background levels, consistent
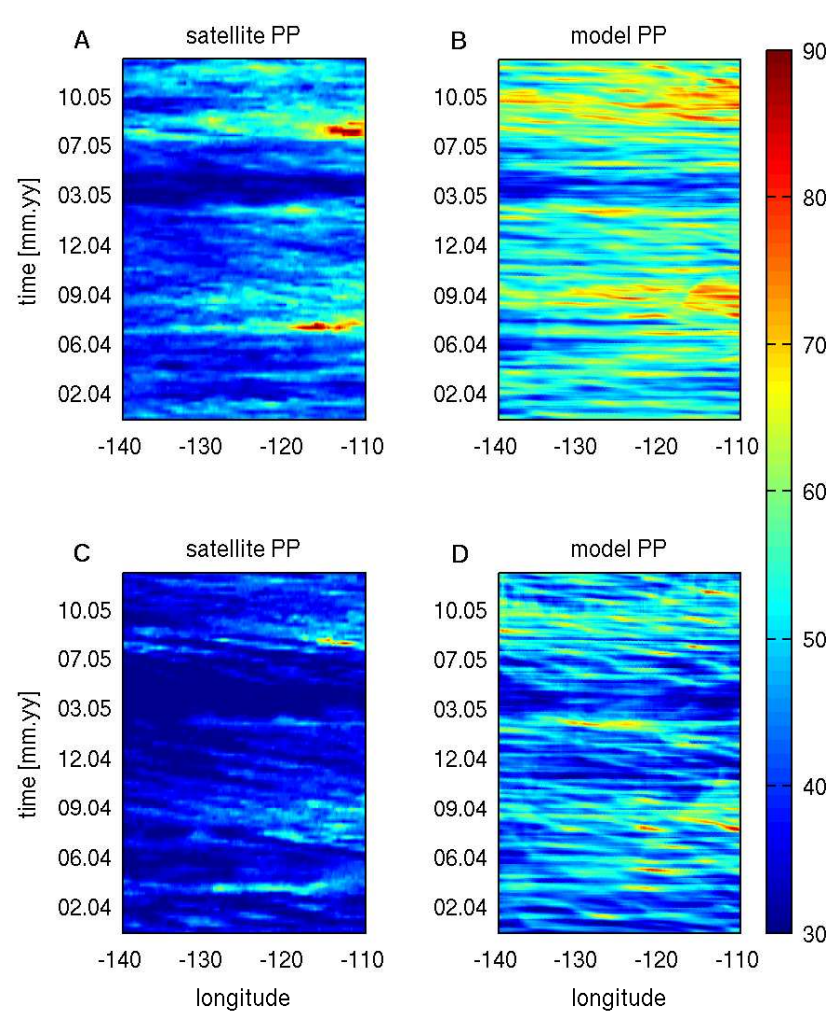

Fig. 6. Time-longitude diagrams of depth integrated and meridional average model and satellite PP in the EEP. Time period is from January 2004 to December 2005. Top panels (A, B) show PP averaged over $1^{\circ} \mathrm{S}-1^{\circ} \mathrm{N}$ and bottom panels $(\mathbf{C}, \mathbf{D})$ show PP averaged over $1^{\circ} \mathrm{N}-3^{\circ} \mathrm{N}$. (A, C) standard VGPM satellite estimate of PP (mmol C m ${ }^{-2} \mathrm{~d}^{-1}$ ) based on Behrenfeld and Falkowski (1997); (B, D) ROMS-CoSiNE PP $\left(\mathrm{mmol} \mathrm{C} \mathrm{m}^{-2} \mathrm{~d}^{-1}\right)$.

with Figs. 3 and 5. In Fig. 6c, d, further away from the equator, the westward propagating bands of alternating increased and decreased PP are especially well visible in both the satellite and model PP fields. Wavelength and period of these features is consistent with known properties of TIWs. Power density spectra of model PP at the equator and at $2^{\circ} \mathrm{N}$ (Figs. S3 and S4) reveal a dominant peak in longer than 100 days period, but also a significant peak in the TIWdominated 20-35 day period window. The latter has a particularly large contribution to total PP variability at $2^{\circ} \mathrm{N}$, consistent with more visible westward propagating features in Fig. 6d. It must be pointed out that the individual waves seen in the model PP fields are definitely not identical to the ones seen by the satellites. This is to be expected considering the differences between the real and model-applied atmospheric forcing.

\subsection{Physical and biological responses to TIWs}

In this section we examine the variability of physical and biological responses to individual TIWs passing through a narrow time-longitude band between $130^{\circ} \mathrm{W}$ and $120^{\circ} \mathrm{W}$, from 
June to December 2004 - the period of most intense TIW activity and one which the model represents accurately compared to satellite and in situ observations (Figs. 4 and 5). During EB cruises, the selected longitude band was characterized by strong ephemeral diatom blooms occurring in response to passing TIWs (Parker et al., 2011). In order to separate patterns of variability due to TIWs from seasonal as well as high-frequency perturbations, we apply a 20-35 day onedimensional band-pass Butterworth filter to time-longitude maps of $\mathrm{SST}$ and $\mathrm{Si}(\mathrm{OH})_{4}$ vertical flux $\left(w \cdot \mathrm{Si}(\mathrm{OH})_{4}\right)$ variability at $0^{\circ} \mathrm{N}$ and $2^{\circ} \mathrm{N}$ (Fig. 7).

At the equator, it is possible to identify individual TIWs in the filtered SST field but rather impossible to do so in the filtered $w \cdot \mathrm{Si}(\mathrm{OH})_{4}$ field (Fig. 7a, b). This is consistent with a lack of one distinct peak in the power density spectrum of the latter (Fig. S1). At $2^{\circ} \mathrm{N}$ six individual TIW events can be clearly identified from lines of maximum negative SST variability (Fig. 7c). When translated onto the filtered $w \cdot \mathrm{Si}(\mathrm{OH})_{4}$ field at $2^{\circ} \mathrm{N}$, the probable TIW tracks coincide with the highest both positive and negative variability, but with negative values being in general more prevalent. A dominant TIW signature in this frequency band in nutrient upwelling fluxes is consistent with a marked peak in the periodogram (Fig. S2) and with previous findings of Friedrichs and Hofmann (2001).

We identify 6 TIW events in the June to December 2004 period, and from now on refer to them as TIWs I-VI, with TIW I occurring the earliest. Estimated TIW tracks approximately follow the lines of maximum negative SST variability during a TIW event (Fig. 8a). Assuming that the leading edges of TIWs coincide with lines of largest negative SST gradient, we note that the leading edge also coincides with a maximum positive gradient in surface $\mathrm{Si}(\mathrm{OH})_{4}$ concentration in all six cases (Fig. 8e). This is not the case for $w$ and $w \cdot \mathrm{Si}(\mathrm{OH})_{4}$ at $75 \mathrm{~m}$ depth, which decrease markedly during the onset of TIW events but increase either in the trailing edge of a passing wave (close to the maximum positive SST gradient) or in between TIW events (Fig. 8b, c). These patterns are no different when considering $w$ averaged over the top $100 \mathrm{~m}$.

Our observations are consistent with the analysis of $w$ fields inside a passing TIV performed by Kennan and Flament (2000), and the analysis of mean upwelling nutrient fluxes at TIW scales of Vichi et al. (2008). The distribution of $w$ and $w \cdot \mathrm{Si}(\mathrm{OH})_{4}$ is very patchy. Thus, we can even observe areas of positive upwelling flux close to the leading edge of a wave (e.g., TIW V in late November 2004). Although local nutrient upwelling flux is unlikely to explain the observed patterns of elevated surface $\mathrm{Si}(\mathrm{OH})_{4}$ (Fig. 8e), it appears to match the timing and extent of at least some areas of elevated $\mathrm{Si}(\mathrm{OH})_{4}$ at $75 \mathrm{~m}$ depth (TIWs III and V). At the onset of these two events, we also observe marked shallowing of the Si nutricline (from 100 to around $50 \mathrm{~m}$; not shown) which, assuming similar variability in $\mathrm{Fe}$ and Si supply, might partially support the hypothesis of Vichi et al. (2008), who con- cluded that if the iron nutricline is shallower than the wave's vertical scale, then the wave can enhance iron availability in the euphotic zone thus leading to a net local increase of phytoplankton biomass. On the other hand, there are no statistically significant peaks in the 20-35 day period window in periodograms of $\mathrm{Si}(\mathrm{OH})_{4}$ at $75 \mathrm{~m}$ depth (Fig. S2). Additionally, during TIWs III and V the discrepancies between the distribution of $\mathrm{Si}(\mathrm{OH})_{4}$ at $75 \mathrm{~m}$ depth and at the surface appear the largest, possibly suggesting that there are other mechanisms, such as meridional distribution of nutrients by TIWs (Gorgues et al., 2005; Vichi et al., 2008; Evans et al., 2009), that regulate the observed pattern of surface $\mathrm{Si}(\mathrm{OH})_{4}$ during this moderately intense summer to winter 2004 TIW season (Strutton et al., 2011).

The same probable TIW tracks are drawn on top of maps of spatio-temporal variability in biological fields (Fig. 9). We can see that positive variability in surface $\mathrm{Si}(\mathrm{OH})_{4}$ concentration is in general matched by an increase in $\rho \mathrm{Si}(\mathrm{OH})_{4}$ and a lagged increase in S2 (large phytoplankton) biomass (Fig.9a, b, d). However, response patterns are not the same for all TIWs recorded in this period. During TIW I, there is much less $\mathrm{S} 2$ near $130^{\circ} \mathrm{W}$ even though there is an equal amount of surface $\mathrm{Si}(\mathrm{OH})_{4}$ along the entire $10^{\circ}$ longitudinal spread of the wave's track. The S2 biomass pattern is correlated with a westward decreasing $\mathrm{Si}(\mathrm{OH})_{4}$ at $75 \mathrm{~m}$ depth but not with any vertical flux. On the other hand, we also observe that ZZ2 (mesozooplankton) biomass is very low at the eastern edge of the box but rather high at the western edge. We know that $\mathrm{S} 2$ must in fact be growing at $130^{\circ} \mathrm{W}$ because of consistently high surface $\rho \mathrm{Si}(\mathrm{OH})_{4}$ along the path of the wave. Thus, it is likely that a large local ZZ2 standing stock keeps the $\mathrm{S} 2$ biomass low despite favorable biogeochemical conditions.

In Fig. 9c we also note that maximum negative variability in PP is observed after the passing of stronger TIWs IV and V, consistent with Evans et al. (2009), who revealed depressed PP after the passage of stronger TIWs or in seasons of deeper thermocline depth. Elsewhere, Gorgues et al. (2005) concluded that TIWs have a net negative effect on PP in this region due to dominant downwelling and horizontal advection of phytoplankton. Despite dominant downwelling at the onset of the TIWs (Fig. 8b, c), and despite the lack of plankton advection in the model, we observe positive PP variability at the onset of the waves, only then followed by a decline in case of TIWs IV and V (Fig. 9c). At the same time, we note no coinciding relative decrease in $\rho \mathrm{Si}(\mathrm{OH})_{4}$ or S2 biomass.

Different conditions are found during the passage of TIW III. Here we observe the weakest $\rho \mathrm{Si}(\mathrm{OH})_{4}$ and $\mathrm{S} 2$ biomass responses to increased surface nutrients. These can be attributed to the high initial population of ZZ2 present in the water column already at the onset of the wave, likely remaining after the previous bloom event. This is confirmed by relatively high PP levels prior to and during TIW III, caused 

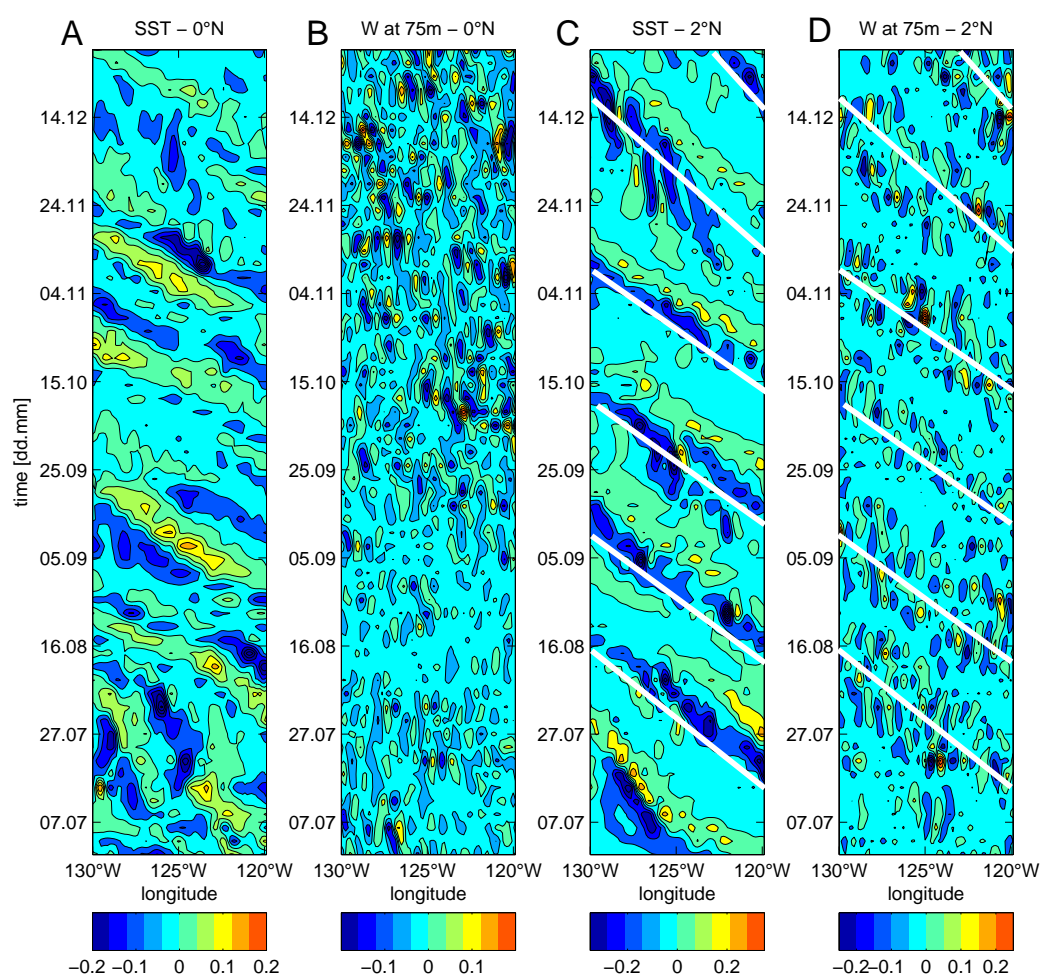

Fig. 7. Time-longitude diagrams of filtered (20-35 day period) ROMS-CoSiNE model fields of: (A) SST and (B) $w$ at $0^{\circ}$ N, and (C) SST and (D) $w$ at $2^{\circ} \mathrm{N}$. Time period is from June 2004 to December 2004. Yellow and orange areas correspond to positive, and dark blue areas to maximum negative variability in the TIW-active period domain. Westward passing wave features in the fields at $2^{\circ} \mathrm{N}$ are identified as TIWs I to VI (from earliest to latest) and their approximate tracks are marked with white lines.
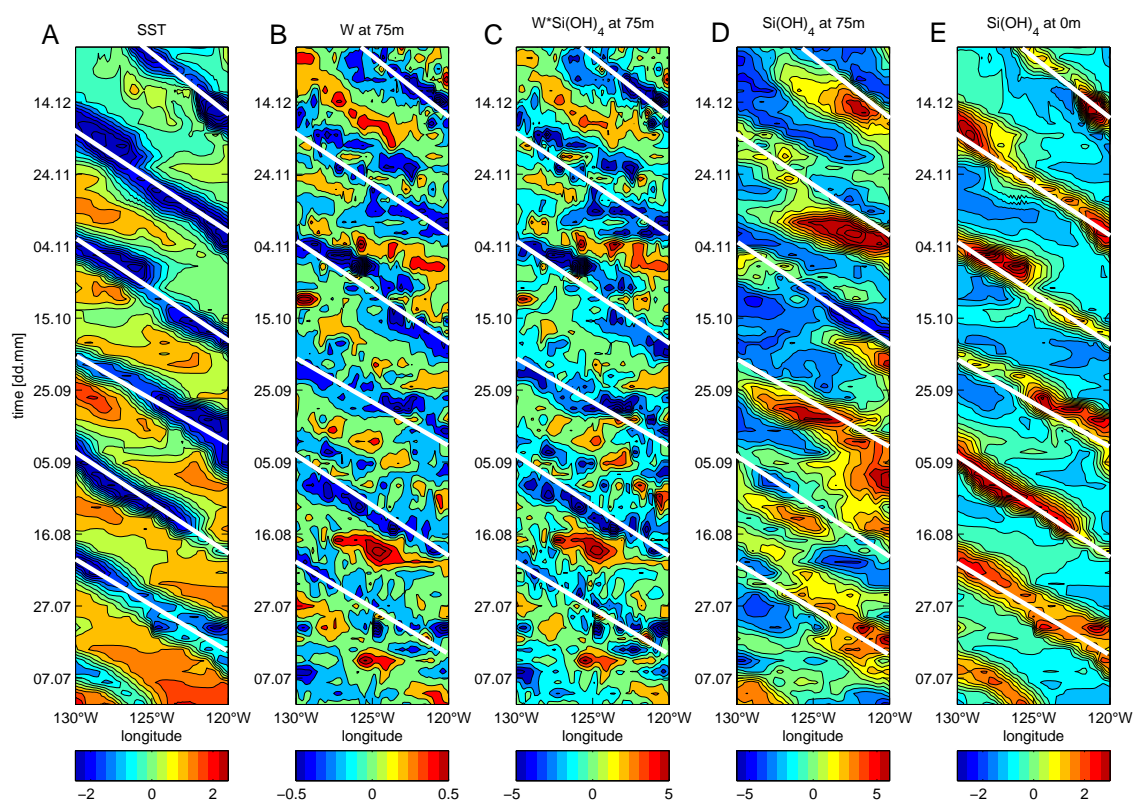

Fig. 8. Time-longitude diagrams of several key physical and chemical fields at $2^{\circ}$ N. Period from June 2004 to December 2004 in days and months (dd.mm); longitude band from $120^{\circ} \mathrm{W}$ to $130^{\circ} \mathrm{W}$. Panels from left to right show the unfiltered variability (mean removed) in: (A)

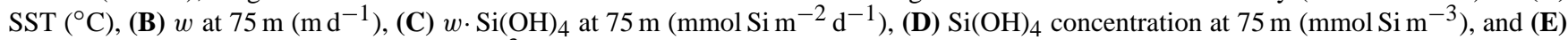
surface $\mathrm{Si}(\mathrm{OH})_{4}$ concentration $\left(\mathrm{mmol} \mathrm{Si} \mathrm{m}^{-3}\right)$. White lines associated with approximate tracks of passing TIWs correspond to likely TIW tracks drawn along maximum negative SST variability in Fig. 7. 

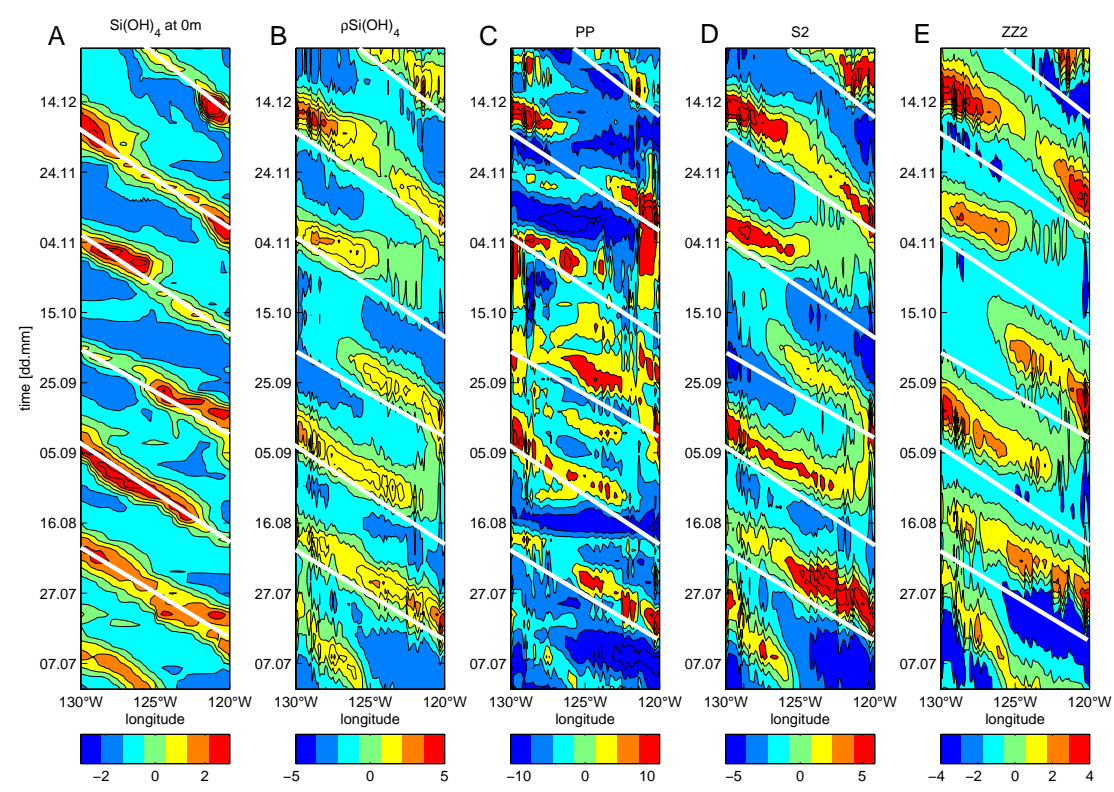

Fig. 9. Same as in Fig. 8 but panels from left to right show the unfiltered variability (mean removed) in: $(\mathrm{A})$ surface $\mathrm{Si}(\mathrm{OH})_{4}$ concentration $\left(\mathrm{mmol} \mathrm{Si} \mathrm{m}^{-3}\right)$ (same as in Fig. $8 \mathrm{e}$ but with fewer contours, repeated for ease of direct comparison), $(\mathbf{B}) \rho \mathrm{Si}(\mathrm{OH})_{4}\left(\mathrm{mmol} \mathrm{Si} \mathrm{m}^{-2} \mathrm{~d}^{-1}\right),(\mathbf{C})$ $\mathrm{PP}\left(\mathrm{mmol} \mathrm{C} \mathrm{m}^{-2} \mathrm{~d}^{-1}\right)$, (D) $\mathrm{S} 2$ and $(\mathbf{E}) \mathrm{ZZ2}$ biomass $\left(\mathrm{mmol} \mathrm{N} \mathrm{m}^{-3}\right)$. White lines are the probable TIW tracks translated from Fig. 8.

by high remineralization activity revealed through elevated $\rho \mathrm{NH}_{4}$ by $\mathrm{S} 1$ (small phytoplankton) (not shown).

It appears that occasionally the pressure from grazers keeps the S2 population at low levels, even during TIW-induced increases of surface nutrients. This may suggest that the initial population of zooplankton is an important factor regulating spatio-temporal patterns in biological responses to TIW events. We acknowledge the fact that under a more realistic setting, both S2 and ZZ2 would partially be advected away. Nevertheless, changes in the initial phytoplankton and zooplankton community structures would likely contribute to the variability in biological production response to TIWs. While to our knowledge this has not been given much attention in TIW-related studies before, initial zooplankton conditions were shown to affect the fate of artificial iron enrichment experiments. During SEEDS (Subarctic Pacific Iron Experiment for Ecosystem Dynamics Study) and SEEDS II iron fertilization experiments (Tsuda et al., 2003, 2007), it was concluded that a large initial population of zooplankton during SEEDS II (not present during SEEDS) was the key factor responsible for suppressing the phytoplankton bloom in response to added Fe. These conclusions were later supported by a modeling study by Fujii and Chai (2009), who suggested that not only mixed layer depth but also the initial biomass of diatoms and its principle grazers are crucial factors in the response of the phytoplankton community to iron enrichments. Our results indicate that similar considerations should be taken into account when designing model and field experiments that examine the role of TIWs on new and primary production in the EEP.

\section{Conclusions}

In this study we examined patterns of spatial and temporal variability in the biological uptake of $\mathrm{NO}_{3}, \mathrm{Si}(\mathrm{OH})_{4}$ and carbon in this region, and evaluated the role of TIW-related biological and physical interactions controlling this variability. High resolution Pacific ROMS-CoSiNE model results were evaluated with in situ and remote sensing data. The results of model-data comparison revealed a good agreement in domain-average hydrographic and biological rate estimates, and patterns of spatio-temporal variability in primary productivity. We confirmed that TIWs have the potential to enhance phytoplankton biomass through an increased supply of nutrients (horizontal and/or vertical) and elevated local and instantaneous phytoplankton nutrient uptake, as opposed to only advecting biomass.

However, there is a tremendous range of variability in both physical and biological flux responses to individual TIW events, likely reflecting changes in TIW intensity and season. Furthermore, we concluded that initial biological conditions (e.g., zooplankton biomass) at the onset of a TIW event may play an important additional constraint on biological responses, in particular of large phytoplankton such as diatoms, to TIW-induced perturbations in the physical and biogeochemical fields and fluxes. In order to advance our efforts to unravel the roles and interactions of regulatory mechanisms in the equatorial Pacific, we recommend improving the CoSiNE model and ecosystem models in general by introducing more phytoplankton groups, variable Redfield and carbon to chlorophyll ratios, as well as a better resolution of the $\mathrm{Fe}-\mathrm{Si}$ co-limitation of phytoplankton growth. 


\section{Supplementary material related to this article is available online at: http://www.biogeosciences.net/9/ 4369/2012/bg-9-4369-2012-supplement.pdf.}

Acknowledgements. The authors would like to thank Huijie Xue, Mary Jane Perry, Mark Wells, Peter Strutton, Wiley Evans, Andy Thomas and Emmanuel Boss for their valuable comments and suggestions. We thank three anonymous reviewers for suggestions that helped us significantly improve the manuscript. We are grateful to Lei Shi and Peng Xiu for assistance in processing the model data. This research was supported by a NASA grant (NNX09AU39G) and NSF (OCE-0961345) to F. Chai. We thank Yi Chao and his group at JPL/NASA for setting up the original Pacific-ROMS model configurations.

Edited by: G. Herndl

\section{References}

Archer, D., Aiken, J., Balch, W., Barber, D., Dunne, J., Flament, P., Gardner, W., Garside, C., Goyet, C., Johnson, E., Kirchman, D., McPhaden, M., Newton, J., Peltzer, E., Welling, L., White, J., and Yoder, J.: A meeting place of great ocean currents: shipboard observations of a convergent front at $2^{\circ} \mathrm{N}$ in the Pacific, DeepSea Res. Pt. II, 44, 1827-1849, 1997.

Arrigo, K. R.: Marine microorganisms and global nutrient cycles, Nature, 437, 349-355, doi:10.1038/nature04159, 2005.

Aufdenkampe, A., McCarthy, J., Navarette, C., Rodier, M., Dunne, J., and Murray, J.: Biogeochemical controls on new production in the tropical Pacific, Deep-Sea Res. Pt. II, 49, 2619-2648, 2002.

Balch, W. M., Poulton, A. J., Drapeau, D. T., Bowler, B. C., Windecker, L. A., and Booth, E. S.: Zonal and meridional patterns of phytoplankton biomass and carbon fixation in the Equatorial Pacific Ocean, between 110 degrees W and 140 degrees W, Deep-Sea Res. Pt. II, 58, 400-416, doi:10.1016/j.dsr2.2010.08.004, 2011.

Behrenfeld, M. and Falkowski, P.: Photosynthetic rates derived from satellite-based chlorophyll concentration, Limnol. Oceanogr., 42, 1-20, 1997.

Behrenfeld, M., Bale, A., Kolber, Z., Aiken, J., and Falkowski, P.: Confirmation of iron limitation of phytoplankton photosynthesis in the equatorial Pacific Ocean, Nature, 383, 508-511, 1996.

Brzezinski, M. A., Baines, S. B., Balch, W. M., Beucher, C. P., Chai, F., Dugdale, R. C., Krause, J. W., Landry, M. R., Marchi, A., Measures, C. I., Nelson, D. M., Parker, A. E., Poulton, A. J., Selph, K. E., Strutton, P. G., Taylor, A. G., and Twining, B. S.: Co-limitation of diatoms by iron and silicic acid in the equatorial Pacific, Deep-Sea Res. Pt. II, 58, 493-511, doi:10.1016/j.dsr2.2010.08.005, 2011.

Campbell, J., Antoine, D., Armstrong, R., Arrigo, K., Balch, W., Barber, R., Behrenfeld, M., Bidigare, R., Bishop, J., Carr, M. E., Esaias, W., Falkowski, P., Hoepffner, N., Iverson, R., Kiefer, D., Lohrenz, S., Marra, J., Morel, A., Ryan, J., Vedernikov, V., Waters, K., Yentsch, C., and Yoder, J.: Comparison of algorithms for estimating ocean primary production from surface chlorophyll, temperature, and irradiance, Global Biogeochem. Cy., 16, 1035, doi:10.1029/2001GB001444, 2002.
Chai, F., Dugdale, R., Peng, T.-H., Wilkerson, F., and Barber, R. One-dimensional ecosystem model of the equatorial Pacific upwelling system. Part I: model development and silicon and nitrogen cycle, Deep-Sea Res. Pt. I, 49, 2713-2745, 2002.

Chai, F., Jiang, M.-S., Chao, Y., Dugdale, R., Chavez, F., and Barber, R. T.: Modeling responses of diatom productivity and biogenic silica export to iron enrichment in the equatorial Pacific Ocean, Global Biogeochem. Cy., 21, GB3S90, doi:10.1029/2006GB002804, 2007.

Chai, F., Liu, G. M., Xue, H. J., Shi, L., Chao, Y., Tseng, C. M., Chou, W. C., and Liu, K. K.: Seasonal and Interannual Variability of Carbon Cycle in South China Sea: A Three-Dimensional Physical-Biogeochemical Modeling Study, J. Oceanogr., 65, 703-720, 2009.

Chavez, F. and Toggweiler, J.: Physical estimates of global new production: the upwelling contribution., in: Upwelling in the Ocean: Modern Processes and Ancient Records, edited by: Summerhayes, C., Emeis, K.-C., Angel, M., Smith, R., and Zeitschel, B., 313-320, Wiley, Chichester, 1995.

Chavez, F. P., Strutton, P. G., and McPhaden, M. J.: Biologicalphysical coupling in the central equatorial Pacific during the onset of the 1997-98 El Niño, Geophys. Res. Lett., 25, 3543-3546, 1998.

Chelton, D., Esbensen, S., Schlax, G., Thum, N., Freilich, M., Wentz, F., Gentemann, C., McPhaden, M., and Schopf, P.: Observations of coupling between surface wind stress and sea surface temperature in the eastern tropical Pacific, J. Climate, 14, 1479-1498, 2001.

Christian, J., Verschell, M., Murtugudde, R., Busalacchi, A., and McClain, C.: Biogeochemical modelling of the tropical Pacific Ocean. II: Iron biogeochemistry, Deep-Sea Res. Pt. II, 49, 545565, 2002.

Dandonneau, Y., Deschamps, P.-Y., Nicolas, J.-M., Loisel, H., Blanchot, J., Montel, Y., Thieuleux, F., and Bécu, G.: Seasonal and interannual variability of ocean color and composition of phytoplankton communities in the North Atlantic, equatorial Pacific and South Pacific, Deep-Sea Res. Pt. II, 51, 303 - 318, doi:10.1016/j.dsr2.2003.07.018, 2004.

Dugdale, R. C. and Wilkerson, F. P.: Silicate regulation of new production in the equatorial Pacific upwelling, Nature, 391, 270273, 1998.

Dugdale, R. C., Barber, R. T., Chai, F., Peng, T. H., and Wilkerson, F. P.: One-dimensional ecosystem model of the equatorial Pacific upwelling system. Part II: sensitivity analysis and comparison with JGOFS EqPac data, Deep-Sea Res. Pt. II, 49, 2747-2768, 2002.

Dugdale, R. C., Wilkerson, F. P., Chai, F., and Feely, R.: Size-fractionated nitrogen uptake measurements in the equatorial Pacific and confirmation of the low Si-high-nitrate lowchlorophyll condition, Global Biogeochem. Cy., 21, GB2005, doi:10.1029/2006GB002722, 2007.

Evans, W., Strutton, P. G., and Chavez, F. P.: Impact of tropical instability waves on nutrient and chlorophyll distributions in the equatorial Pacific, Deep-Sea Res. Pt. I, 56, 178-188, 2009.

Flament, P., Kennan, S., Knox, R., Niiler, P., and Bernstein, R.: The three-dimensional structure of an upper ocean vortex in the tropical Pacific Ocean, Nature, 383, 610-613, 1996.

Foley, D., Dickey, T., McPhaden, M., Bidigare, R., Lewis, M., Barber, R., Lindley, S., Garside, C., Manov, D., and McNeil, J.: 
Longwaves and primary productivity variations in the equatorial Pacific at $0^{\circ}, 140^{\circ} \mathrm{W}$, Deep-Sea Res. Pt. II, 44, 1801-1826, doi:10.1016/S0967-0645(97)00080-5, 1997.

Friedrichs, M. A. M. and Hofmann, E. E.: Physical control of biological processes in the central equatorial Pacific Ocean, DeepSea Res. Pt. I,, 48, 1023-1069, 2001.

Friedrichs, M. A. M., Carr, M.-E., Barber, R. T., Scardi, M., Antoine, D., Armstrong, R. A., Asanuma, I., Behrenfeld, M. J., Buitenhuis, E. T., Chai, F., Christian, J. R., Ciotti, A. M., Doney, S. C., Dowell, M., Dunne, J., Gentili, B., Gregg, W., Hoepffner, N., Ishizaka, J., Kameda, T., Lima, I., Marra, J., Melin, F., Moore, J. K., Morel, A., O’Malley, R. T., O'Reilly, J., Saba, V. S., Schmeltz, M., Smyth, T. J., Tjiputra, J., Waters, K., Westberry, T. K., and Winguth, A.: Assessing the uncertainties of model estimates of primary productivity in the tropical Pacific Ocean, J. Mar. Syst., 76, 113-133, 2009.

Fujii, M. and Chai, F.: Influences of initial plankton biomass and mixed-layer depths on the outcome of iron-fertilization experiments, Deep-Sea Res. Pt. II, 56, 2936-2947, 2009.

Gorgues, T., Menkes, C., Aumont, O., Vialard, J., Dandonneau, Y., and Bopp, L.: Biogeochemical impact of tropical instability waves in the equatorial Pacific, Geophys. Res. Lett., 32, L24615, doi:10.1029/2005GL024110, 2005.

Gorgues, T., Menkes, C., Slemons, L., Aumont, O., Dandonneau, Y., Radenac, M. H., Alvain, S., and Moulin, C.: Revisiting the La Nina 1998 phytoplankton blooms in the equatorial Pacific, Deep-Sea Res. Pt. I, 57, 567-576, 2010.

Jiang, M. S., Chai, F., Dugdale, R. C., Wilkerson, F. P., Peng, T. H., and Barber, R. T.: A nitrate and silicate budget in the equatorial Pacific Ocean: a coupled physical-biological model study, DeepSea Res. Pt. II, 50, 2971-2996, 2003.

Jolliff, J. K., Kindle, J. C., Shulman, I., Penta, B., Friedrichs, M. A. M., Helber, R., and Arnone, R. A.: Summary diagrams for coupled hydrodynamic-ecosystem model skill assessment, J. Mar. Syst., 76, 64-82, 2009.

Kalnay, E., Kanamitsu, M., Kistler, R., Collins, W., Deaven, D., Gandin, L., Iredell, M., Saha, S., White, G., Woollen, J., Zhu, Y., Chelliah, M., Ebisuzaki, W., Higgins, W., Janowiak, J., Mo, K. C., Ropelewski, C., Wang, J., Leetmaa, A., Reynolds, R., Jenne, R., and Joseph, D.: The NCEP/NCAR 40-year reanalysis project, B. Am. Meteorol. Soc., 77, 437-471, 1996.

Kaupp, L. J., Measures, C. I., Selph, K. E., and Mackenzie, F. T.: The distribution of dissolved $\mathrm{Fe}$ and $\mathrm{Al}$ in the upper waters of the Eastern Equatorial Pacific, Deep-Sea Res. Pt. II, 58, 296-310, doi:10.1016/j.dsr2.2010.08.009, 2011.

Kennan, S. and Flament, P.: Observations of a tropical instability vortex, J. Phys. Oceanogr., 30, 2277-2301, 2000.

Kessler, W. and McPhaden, M.: Oceanic equatorial waves and the 1991-93 El Niño, J. Climate, 8, 1757-1774, doi: 10.1175/15200442(1995)008<1757:OEWATE > 2.0.CO;2, 1995.

Krause, J. W., Nelson, D. M., and Brzezinski, M. A.: Biogenic silica production and the diatom contribution to primary production and nitrate uptake in the eastern equatorial Pacific Ocean, DeepSea Res. Pt. II, 58, 434-448, doi:10.1016/j.dsr2.2010.08.010, 2011.

Landry, M. R., Selph, K. E., Taylor, A. G., Decima, M., Balch, W. M., and Bidigare, R. R.: Phytoplankton growth, grazing and production balances in the HNLC equatorial Pacific, Deep-Sea Res. Pt. II, 58, 524-535, doi:10.1016/j.dsr2.2010.08.011, 2011.
Large, W. G. and Pond, S.: Sensible and latent heat flux measurements over the ocean, J. Phys. Oceanogr., 12, 464-482, 1982.

Lawrence, S. and Angell, J.: Evidence for Rossby wave control of tropical instability waves in the Pacific ocean, Geophys. Res. Lett., 27, 2257-2260, 2000.

Lee, T. and McPhaden, M.: Increasing intensity of El Niño in the central-equatorial Pacific, Geophys. Res. Lett., 37, L14603, doi:10.1029/2010GL044007, 2010.

Lee, T., Lagerloef, G., Gierach, M., Kao, H., Yueh, S., and Dohan, K.: Aquarius reveals salinity structure of tropical instability waves, Geophys. Res. Lett., 39, L12610, doi:10.1029/2012GL052232, 2012.

Liu, G. and Chai, F.: Seasonal and interannual variability of primary and export production in the South China Sea: a threedimensional physical-biogeochemical model study, Ices J. Mar. Sci., 66, 420-431, 2009.

Lyman, J., Johnson, G., and Kessler, W.: Distinct 17-and 33-day tropical instability waves in subsurface observations, J. Phys. Oceanogr., 37, 855-872, 2007.

Mantua, N. J. and Hare, S. R.: The Pacific decadal oscillation, J. Oceanogr., 58, 35-44, 2002.

McCarthy, J. J., Garside, C., Nevins, J. L., and Barber, R. T.: New production along $140^{\circ} \mathrm{W}$ in the equatorial Pacific during and following the 1992 El Niño event, Deep-Sea Res. Pt. II, 43, 10651093, 1996.

McClain, C., Christian, J. R., Signorini, S. R., Lewis, M. R., Asanuma, I., Turk, D., and Dupouy-Douchement, C.: Satellite ocean color observations of the tropical Pacific Ocean, Deep-Sea Res. Pt. II, 49, 2533-2560, 2002.

Menkes, C., Kennan, S., Flament, P., Dandonneau, Y., Masson, S., Biessy, B., Marchal, E., Eldin, G., Grelet, J., Montel, Y., Morliere, A., Lebourges, A., Moulin, C., Champalbert, G., and Herbland, A.: A whirling ecosystem in the equatorial Atlantic, Geophys. Res. Lett., 29, 1553, doi:10.1029/2001GL014576, 2002.

Mestas-Nunez, A. M. and Miller, A. J.: Interdecadal variability and climate change in the eastern tropical Pacific: A review, Prog. Oceanogr., 69, 267-284, 2006.

Minas, H., Minas, M., and Packard, T.: Productivity in upwelling areas deduced from hydrographic and chemical fields, Limnol. Oceanogr., 31, 1182-1206, 1986.

Nelson, D. M. and Landry, M. R.: Regulation of phytoplankton production and upper-ocean biogeochemistry in the eastern equatorial Pacific: Introduction to results of the Equatorial Biocomplexity project, Deep-Sea Res. Pt. II, 58, 277-283, doi:10.1016/j.dsr2.2010.08.001, 2011.

Palacz, A. P., Chai, F., Dugdale, R. C., and Measures, C. I.: Estimating iron and aluminum removal rates in the eastern equatorial Pacific Ocean using a box model approach, Deep-Sea Res. Pt. II, 58, 311-324, doi:10.1016/j.dsr2.2010.08.012, 2011.

Parker, A. E., Wilkerson, F. P., Dugdale, R. C., Marchi, A. M., Hogue, V. E., Landry, M. R., and Taylor, A. G.: Spatial patterns of nitrogen uptake and phytoplankton in the equatorial upwelling zone $\left(110^{\circ} \mathrm{W}-140^{\circ} \mathrm{W}\right)$ during 2004 and 2005 , Deep-Sea Res. Pt. II, 58, 417-433, doi:10.1016/j.dsr2.2010.08.013, 2011.

Pena, M., Lewis, M., and Cullen, J.: New production in the warm waters of the tropical Pacific Ocean, J. Geophys. Res.-Oceans, 99, 14255-14268, 1994.

Pennington, J. T., Mahoney, K. L., Kuwahara, V. S., Kolber, D. D., Calienes, R., and Chavez, F. P.: Primary production in the eastern 
tropical Pacific: A review, Prog. Oceanogr., 69, 285-317, 2006.

Philander, S.: Instabilities of zonal equatorial currents, J. Geophys. Res., 83, 3679-3682, 1978.

Salihoglu, B. and Hofmann, E. E.: Simulations of phytoplankton species and carbon production in the equatorial Pacific Ocean 2. Effects of physical and biogeochemical processes, J. Mar. Res., 65, 275-300, 2007.

Selph, K. E., Landry, M. R., Taylor, A. G., Yang, E.-J., Measures, C. I., Yang, J., Stukel, M. R., Christensen, S., and Bidigare, R. R.: Spatially-resolved taxon-specific phytoplankton production and grazing dynamics in relation to iron distributions in the Equatorial Pacific between 110 and $140^{\circ} \mathrm{W}$, Deep-Sea Res. Pt. II, 58, 358-377, doi:10.1016/j.dsr2.2010.08.014, 2011.

Strutton, P. G., Ryan, J. P., and Chavez, F. P.: Enhanced chlorophyll associated with tropical instability waves in the equatorial Pacific, Geophys. Res. Lett., 28, 2005-2008, 2001.

Strutton, P. G., Palacz, A. P., Dugdale, R. C., Chai, F., Marchi, A., Parker, A. E., Hogue, V., and Wilkerson, F. P.: The impact of equatorial Pacific tropical instability waves on hydrography and nutrients: 2004-2005, Deep-Sea Res. Pt. II, 58, 284-295, doi:10.1016/j.dsr2.2010.08.015, 2011.

Stukel, M. R., Landry, M. R., and Selph, K. E.: Nanoplankton mixotrophy in the eastern equatorial Pacific, Deep-Sea Res. Pt. II, 58, 378-386, doi:10.1016/j.dsr2.2010.08.016, 2011.

Takahashi, T., Sutherland, S., Feely, R., and Cosca, C.: Decadal variation of the surface water $\mathrm{PCO} 2$ in the western and central equatorial Pacific, Science, 302, 852-856, 2003.

Taylor, A. G., Landry, M. R., Selph, K. E., and Yang, E. J.: Biomass, size structure and depth distributions of the microbial community in the eastern equatorial Pacific, Deep-Sea Res. Pt. II, 58, 342 357, doi:10.1016/j.dsr2.2010.08.017, 2011.

Tsuda, A., Takeda, S., Saito, H., Nishioka, J., Nojiri, Y., Kudo, I., Kiyosawa, H., Shiomoto, A., Imai, K., Ono, T., Shimamoto, A., Tsumune, D., Yoshimura, T., Aono, T., Hinuma, A., Kinugasa, M., Suzuki, K., Sohrin, Y., Noiri, Y., Tani, H., Deguchi, Y., Tsurushima, N., Ogawa, H., Fukami, K., Kuma, K., and Saino, T.: A Mesoscale Iron Enrichment in the Western Subarctic Pacific Induces a Large Centric Diatom Bloom, Science, 300, 958-961, doi:10.1126/science.1082000, 2003.

Tsuda, A., Takeda, S., Saito, H., Nishioka, J., Kudo, I., Nojiri, Y., Suzuki, K., Uematsu, M., Wells, M., Tsumune, D., Yoshimura, T., Aono, T., Aramaki, T., Cochlan, W., Hayakawa, M., Imai, K., Isada, T., Iwamoto, Y., Johnson, W., Kameyama, S., Kato, S., Kiyosawa, H., Kondo, Y., Levasseur, M., Machida, R., Nagao, I., Nakagawa, F., Nakanishi, T., Nakatsuka, S., Narita, A., Noiri, Y., Obata, H., Ogawa, H., Oguma, K., Ono, T., Sakuragi, T., Sasakawa, M., Sato, M., Shimamoto, A., Takata, H., Trick, C., Watanabe, Y., Wong, C., and Yoshie, N.: Evidence for the grazing hypothesis: Grazing reduces phytoplankton responses of the HNLC ecosystem to iron enrichment in the western subarctic pacific (SEEDS II), J. Oceanogr., 63, 983-994, doi:10.1007/s10872-007-0082-x, 2007.
Turk, D., Meinen, C., Antoine, D., McPhaden, M., and Lewis, M.: Implications of changing El Niño patterns for biological dynamics in the equatorial Pacific Ocean, Geophys. Res. Lett., 38, L23603, doi:10.1029/2011GL049674, 2011.

Vecchi, G. A. and Wittenberg, A. T.: El Nino and our future climate: where do we stand?, Wiley Interdisciplinary Reviews, Climate Change, 1, 260-270, 2010.

Vichi, M., Masina, S., and Nencioli, F.: A process-oriented model study of equatorial Pacific phytoplankton : the role of iron supply and tropical instability waves, Prog. Oceanogr., 78, 147-162, 2008.

Wang, X. C. and Chao, Y.: Simulated Sea Surface Salinity variability in the tropical Pacific, Geophys. Res. Lett., 31, L02302, doi:10.1029/2003GL018146, 2004.

Wang, C. Z. and Fiedler, P. C.: ENSO variability and the eastern tropical Pacific: A review, Prog. Oceanogr., 69, 239-266, 2006.

Wang, X., Christian, J. R., Murtugudde, R., and Busalacchi, A. J.: Spatial and temporal variability of the surface water $p \mathrm{CO}_{2}$ and air-sea $\mathrm{CO}_{2}$ flux in the equatorial Pacific during 1980-2003: a basin-scale carbon cycle model, J. Geophys. Res.-Oceans, 111, C07S04, doi:10.1029/2005JC002972, 2006.

Wells, M. L., Vallis, G. K., and Silver, E. A.: Tectonic processes in Papua New Guinea and past productivity in the eastern equatorial Pacific Ocean, Nature, 398, 601-604, 1999.

Westberry, T., Behrenfeld, M. J., Siegel, D. A., and Boss, E.: Carbon-based primary productivity modeling with vertically resolved photoacclimation, Global Biogeochem. Cy., 22, GB2024, doi:10.1029/2007GB003078, 2008.

Xiu, P. and Chai, F.: Modeling the effects of size on patch dynamics of an inert tracer, Ocean Sci., 6, 413-421, doi:10.5194/os-6-4132010, 2010.

Xiu, P. and Chai, F.: Modeled biogeochemical responses to mesoscale eddies in the South China Sea, J. Geophys. Res., 116, doi:10.1029/2010JC006800, 2011.

Xiu, P., Chai, F., Shi, L., Xue, H. J., and Chao, Y.: A census of eddy activities in the South China Sea during 1993-2007, J. Geophys. Res.-Oceans, 115, 2010.

Xiu, P., Palacz, A. P., Chai, F., Roy, E. G., and Wells, M. L.: Iron flux induced by Haida eddies in the Gulf of Alaska, Geophys. Res. Lett., 38, L13607, doi:10.1029/2011GL047946, 2011.

Yoder, J., Ackleson, S. G., Barber, R., Flament, P., and Balch, W.: A line in the sea, Nature, 371, 689-692, 1994.

Zhang, H. M., Bates, J. J., and Reynolds, R. W.: Assessment of composite global sampling: Sea surface wind speed, Geophys. Res. Lett., 33, L17714, doi:10.1029/2006GL027086, 2006. 